\title{
Recent Advances of Imidazolin-2-iminato in Transition Metal Chemistry
}

\author{
Preethi Raja ${ }^{1}$, Shanmugam Revathi ${ }^{1}$ and Tapas Ghatak ${ }^{1, *}$
}

\begin{abstract}
A new class of monoanionic nitrogen donor ligands imidazolin-2-iminato $\left(1 \mathrm{~m}^{R} \mathrm{~N}^{-}\right)$is produced from the reactivity of $\mathrm{N}$ heterocyclic carbenes ( $\mathrm{NHCs}$ ) towards organic azides and is isolobally related to imido ligands ( $\left.\mathrm{RN}^{2-}\right)$. The imidazolin-2-iminato ligands essentially can be derived by substituting alkyl or aryl group from imido moieties. The proton abstraction from imidazolin-2-imine results in the monoanionic imidazolin-2-iminato ligands that possesses the exocyclic nitrogen, which strongly favors the binding with electrophiles. The nucleophilicity of anionic nitrogen is markedly increased by the charge (positive) delocalization into the five-membered heterocyclic ring. Altering the $\mathrm{N}$-substitutions could meet the necessities for kinetic stabilization of high valent reactive species. These ligands have been slowly cemented the status as a potential alternative for ubiquitous cyclopentadienyl ligand and continued receiving attention. These ligands have progressively accustomed as the ancillary ligands for early transition metals, rare earth elements, or early actinides affording pincer complexes or "pogo stick" type compounds. In this article, the present chemistry of transition metal elements bearing imidazolin-2-iminato/imine ligands is reviewed from the year 2015 to date.
\end{abstract}

Keywords: N-heterocyclic carbene; Catalysis; Polymerization; Metathesis; Transition metal; Hydroamination; Hydroboration. Received: 20 Septembert 2020; Accepted: 12 November 2020.

Article type: Review article.

\section{Introduction}

Nitrogen, the third most electronegative element in the periodic table, is recognized as one of the most familiar donor heteroatoms in coordination chemistry. Notably, the coordination ability of carbon was established by following the first reports of N-heterocyclic carbene (NHC) independently by Öfele, ${ }^{[1]}$ Wanzlick, ${ }^{[2]}$ and Lappert. ${ }^{[3]}$ Despite the significant advancement accomplished by these groups, the topic was not so appealing until the seminal report appeared on the first structural characterization of NHC by A. J. Arduengo III, which immediately turned out to be leading research areas in the field of organometallic and catalysis, ${ }^{[4-16]}$ medicinal chemistry, ${ }^{[17-21]}$ material science, ${ }^{[22-27]}$ and organocatalysis. ${ }^{[28-29]}$ NHCs received considerable attention due to the high thermal stability, ease of preparation, and nontoxic character ${ }^{[30-32]}$ Although NHCs were introduced as potential alternatives for phosphines in organometallic chemistry, they have been applied widely in diverse fields of

\footnotetext{
${ }^{I}$ Vellore Institute of Technology, Vellore. India

* Email: tapas.ghatak@vit.ac.in (T. Ghatak)

Dedicated to Prof. Moris S. Eisen on the occasion of his $60^{\text {th }}$ birthday.
}

chemistry. One of such applications of NHCs is the synthesis of silylenes, a class of divalent silicon compound. ${ }^{[33-35]}$ Recently silylenes have received considerable attention due to their potential applications in the field of catalysis. ${ }^{[36]}$ For example, Cui and co-workers successfully employed bulky NHC (1,3-bis(tert-butyl)imidazol-2-ylidene) for the synthesis of cyclic silylenes via dehydrochlorination of cyclic diaminohydrochlorosilanes. ${ }^{[37]}$ This was the maiden report of metal-free cyclic silylenes synthesis under mild reaction conditions. The reactivity studies of silylenes were extensively explored towards carbonyls, imines, alkenes, and alkynes substrates. However, the low reactivity of nitrile is restricted further for this study. Cui and co-workers recently demonstrated the unique reactivity of NHC stabilized silylenes towards various unsaturated substrates. The NHC-stabilized silylene was successfully utilized for bis-silylation of nitriles to achieve highly regioselective corresponding trans-1,2disilylimines. ${ }^{[38]}$ The pivotal role of the imidazole ring to stabilize the positive charge ${ }^{[39-42]}$ is the rationale for the high nucleophilicity of NHC. ${ }^{[43-44]}$ Rational design by introducing exocyclic $\mathrm{NH}$ at 2-position of the NHC ring resulted in imidazolin-2-imine with higher nucleophilicity and basicity comparable to the parent NHC. The formation of a stable imidazolium center leads to a significant electron density dissemination from the heterocycle ring to the exocyclic 
nitrogen atom through the formation of the formally zwitterionic structure, demonstrated by conceivable canonical structures of the monoanionic imidazolin-2-iminato ligand I (Scheme 1). ${ }^{[45]}$<smiles>[R]N1C=CN(CC)C12CCN(C)C2</smiles>

I

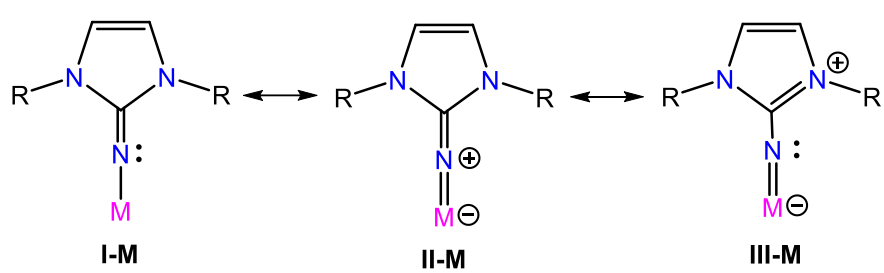

Scheme 1. The canonical form of the anionic imidazolin-2iminato ligand, and model transition metal complexes.

The exocyclic nitrogen atom in canonical form II is carrying two formal charges, which enhance the electrondonating ability. Whereas partial N-heterocyclic carbene (NHC) character is displayed by form III (Scheme 1). Hence, imidazolin-2-iminato behaves as $2 \sigma, 4 \pi$ electron donors, ${ }^{[46]}$ resembling the cyclopentadienyl $(\mathrm{Cp})$ ligand as both are 6 electrons donors and evident from the canonical structures (IIII) depicted in scheme 1 . The metal complexes of imidazolin2-iminato (I-M) showed significant metalla-2-aza-allene (IIM) or metal imide (III-M) character (Scheme 1). The canonical forms are revealed in the lengthening of $\mathrm{C}_{\mathrm{ipso}}-\mathrm{N}_{\mathrm{exo}}$ bond distance and shortening of the $\mathrm{M}-\mathrm{N}_{\text {exo }}$ distance. The linear $\mathrm{C}-\mathrm{N}-\mathrm{M}$ disposition identical to $\mathrm{CCC}$ allene is the manifestation of strong metal-nitrogen interaction. The imidazolin-2-iminato $\left(\mathrm{Im}^{\mathrm{R}} \mathrm{N}^{-}\right)$ligand, which is monoanionic, could be used for the synthesis of numerous transition metal complexes. ${ }^{[47-48]}$ The steric and electronic parameters of the ligand can be tailored by altering the wingtip substituents on nitrogen atoms, which in turn affects the catalytic performance of the complexes and may be used to fine-tune the kinetic protection of the coordinated metal. The five-membered azole ring is featuring the more open coordination sphere by keeping away the 1,3-substituents from the metal center, critical for the polymerization of $\alpha$-olefins. During two decades, $\operatorname{Im}^{\mathrm{R}} \mathrm{N}^{-}$ $/ \mathrm{Im}^{\mathrm{R}} \mathrm{NH}$ ligands have been explored thoroughly with the transition metal system owing to their unique structural motif of easily achievable flexible coordination modes by rational design. The design of a new class of ligand systems with identical electronic characteristics to imidazolin-2-imines is highly desired. The efforts are on to extend the members of the $\mathrm{N}$-heterocyclic imine class either by introducing the phenyl ring at the backbone of the imidazole ring or extend its ring size (IV-VI) (Scheme 2) ${ }^{[49-51]}$

The synthesis, catalytic applications and the significance of transition metal complexes containing imidazolin-2iminato ligands in the field of homogeneous catalysis are briefly presented in this review. Catalytic applications, covered in the current review, are olefin polymerization, hydroamination, ring-opening metathesis (ROP), hydroboration, and metathesis reactions. All metal complexes were synthesized by utilizing $\mathrm{N}$-silylated 2-iminoimidazolines, imidazolin-2-imine, and lithiated imidazolin-2-iminato. In general, N-silylated 2-iminoimidazolines and lithiated imidazolin-2-iminato were exploited in synthesizing metal complexes starting with halide metal precursors. The tunable steric and electronic features of imidazolin-2-iminato supported transition metal complexes and its impact on the catalytic efficiencies are briefly discussed. A related review of transition metal-containing imidazolin-2-iminato ligands was covered till 2014..$^{[52]}$ Thus, the recent progress of this field starting from 2015 to date is briefly documented in the current review. Further, the future scopes and possible structural modifications of the transition metal complexes bearing imidazolin-2-iminato/ $\mathrm{N}$-heterocyclic iminato moieties by altering ring size are also presented herein. ${ }^{[49-51]}$

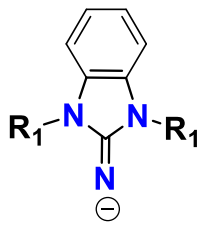

IV

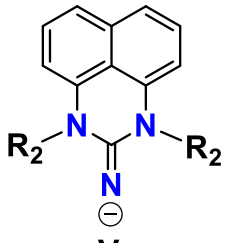

V

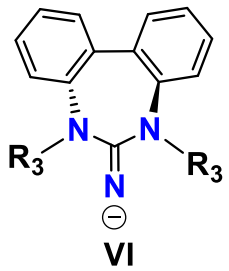

VI
Scheme 2. Schematic presentations of the new members of the N-heterocyclic iminato moiety.

\section{Synthesis of $\mathbf{N}$-silylated 2-iminoimidazolines}

Tamm et al. introduced the synthetic protocol of imidazolin2 -imine by the Staudinger reaction ${ }^{[53]}$ of 1,3-di-tert-butyl imidazolin-2-ylidene 1a with $\mathrm{N}_{3} \mathrm{Si}\left(\mathrm{CH}_{3}\right)_{3}$ in boiling toluene for 72 hours to afford the N-silylated 2-iminoimidazoline 2a (Scheme 3). The formation of carbenes (1a and $\mathbf{1 b}$ ) was identified in ${ }^{1} \mathrm{H}$ NMR as the appearance of two backbone $\mathrm{NCH}$ protons in high-field shifts of $-0.74 \mathrm{ppm}\left(\mathbf{1 a}, \mathrm{R}^{1}=\mathrm{H}\right)$ and $0.72 \mathrm{ppm}\left(\mathbf{1} \mathbf{b}, \mathrm{R}^{1}=\mathrm{H}\right)$ upon the formation of corresponding imine $\mathbf{2 a}$ and $\mathbf{2 b}$, respectively. ${ }^{[54]}$

The formation of $\mathbf{2 c}$ from $\mathbf{1 c}$ was confirmed by the lowfield shift of the septet resonance of $\mathrm{CH}$ proton of the wingtip isopropyl group from 3.95 to $4.61 \mathrm{ppm}$. The ${ }^{1} \mathrm{H}$ and ${ }^{13} \mathrm{C}$ NMR spectra indicate the pseudo- $\mathrm{C}_{2 \mathrm{v}}$ symmetry of $\mathbf{2}$ in solution. The detailed X-ray structure analysis of $\mathbf{2 a}$ revealed that the exocyclic $\mathrm{C}-\mathrm{N}$ bond distance of 1.275(3) $\AA$ is significantly shorter than the corresponding distance in 2-imino-1,3dimethylimidazoline of 1.296(2) $\AA .{ }^{[55]}$

\section{Synthesis of 2-iminoimidazolines}

Extensive applications of the $\mathrm{N}$-silylated 2-iminoimidazolines 


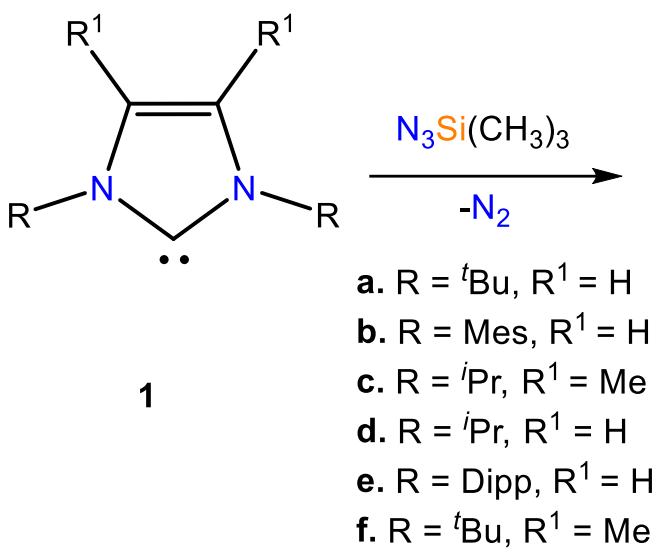

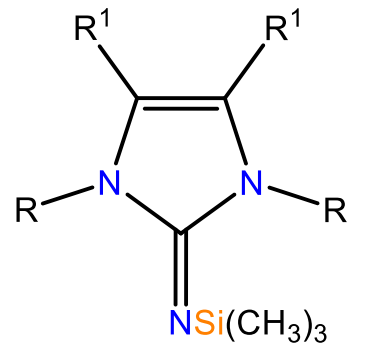

2

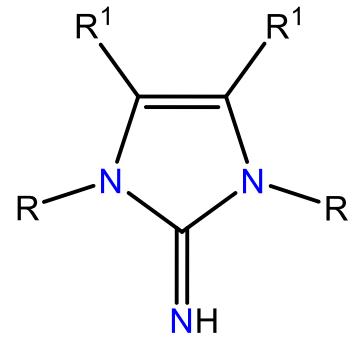

3

Scheme 3. Synthesis of N-silylated 2-iminoimidazolines (2) and 2-iminoimidazolines (3).

were not only limited to the synthesis of numerous transition metal complexes. Rather, the respective desilylated 2iminoimidazolines were also exploited as valuabe ligands for the advancement of organometallic chemistry of lanthanides and actinides. Initially, the syntheses of 2-iminoimidazolines were achieved by a multistep synthetic protocol starting from 2-aminoimidazole. ${ }^{[56]}$ Later on, Tamm and co-workers developed a desilylation method that allowed a convenient access to 2-iminoimidazolines from $\mathrm{N}$-silylated 2iminoimidazolines with various $\mathrm{N}$-substitutions (Scheme 3).

\section{Imidazolin-2-iminato transition-metal complexes 4.1. Titanium complexes}

4.1.1. Synthesis of titanium complex from $\mathrm{N}$-silylated 2iminoimidazolines

The reaction between $\mathrm{N}$-silylated 2-iminoimidazolines and metal halide is one of the major synthetic protocols for preparing imidazolin-2-iminato metal complexes. The imidazolin-2-iminato titanium complexes were synthesized by following the identical synthetic protocol of complexation reaction of silylated iminophosphoranes with various metal halides to afford phosphoraneiminato complexes with the removal of trialkylsilyl halides. ${ }^{[57-58]}$ The room temperature treatment of $\mathrm{TiCl}_{4}$ in hexane with one and two equivalent of the imine resulted in the corresponding orange crystalline Ti(IV) complex $\mathbf{3}$ and $\mathbf{4}$. Subsequent methylation of complex 4 with methyllithium afforded corresponding methylated complexes $\mathbf{5}$ in a moderate yield. The mixed imidazolin-2iminato and cyclopentadienyl titanium complex $\mathbf{6}$ was also synthesized identically by the reaction of $\left[\left(\eta^{5}-\mathrm{C}_{5} \mathrm{H}_{5}\right) \mathrm{TiCl}_{3}\right]$ with 2 (Scheme 4). The central metal ion in $\mathbf{6}$ is coordinated with two chloride ligands, one cyclopentadienyl, and one imidazolin-2-iminato ligand completing a pseudo-tetrahedral geometry. The complex 6 displayed a short Ti- $\mathrm{N}_{\text {imine }}(1.765(3)$ $\AA$ ) bond distance accredited to the efficient $\pi$-donation of imidazolin-2-iminato moiety. The $\mathrm{Cl}-\mathrm{Ti}-\mathrm{Cl}, \mathrm{Cl}-\mathrm{Ti}-\mathrm{N}$ angles were found to be $102.10(3)^{\circ}$ and $103.47(5)^{\circ}$, respectively. However, relatively longer Ti-N bond distance and significant deviation from the linearity of $\mathrm{Ti}-\mathrm{N}-\mathrm{C}$ angle in saturated imidazolidin-2-iminato titanium complex were observed. ${ }^{[59]}$
The treatment of $\mathbf{6}$ with methyllithium resulted in the formation of corresponding methylated compounds 7 .

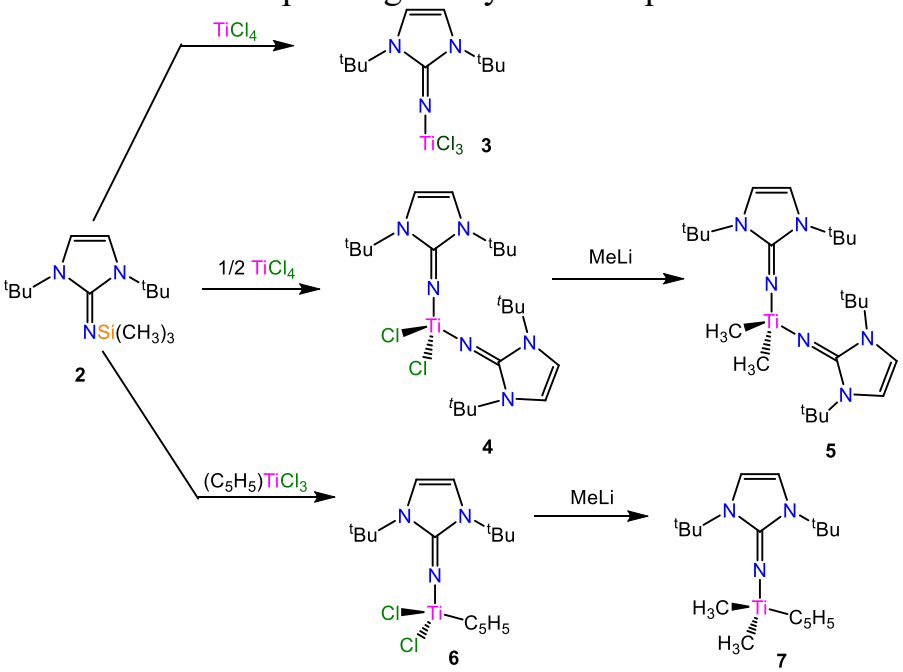

Scheme 4. Synthesis of imidazolin-2-iminato Ti complex by desilylation of $\mathrm{N}$-silylated 2-iminoimidazoline.

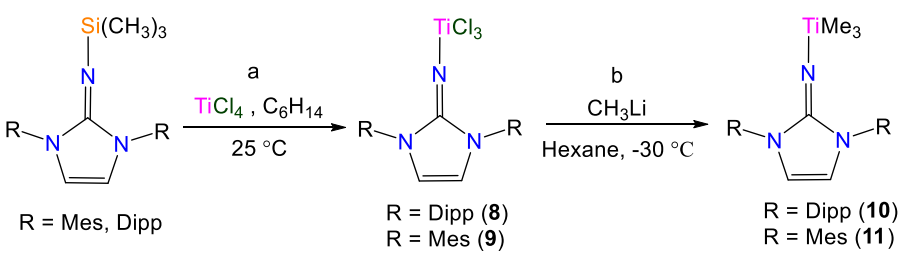

Scheme 5. Synthesis of Ti complex with bulky imidazolin-2iminato ligands.

Eisen and co-workers synthesized the Ti complexes $\mathbf{8}$ and 9 containing the bulky imidazolin-2-iminato ligands following the same aforementioned protocol (Scheme 5a) ${ }^{[60]}$ Subsequent treatment with $\mathrm{CH}_{3} \mathrm{Li}$ at $-30^{\circ} \mathrm{C}$ afforded the corresponding methylated complexes $\mathbf{1 0}$ and $\mathbf{1 1}$ (Scheme 5b). The central metal atom in $\mathbf{8}$ and $\mathbf{9}$ are coordinated with three chlorine atom and one imidazolin-2-iminato ligand exhibiting a tetrahedral geometry. The X-ray structure of $\mathbf{8}$ and $\mathbf{9}$ displayed short Ti$\mathrm{N}_{\text {imine }}$ bond distances (1.731(3) $\AA$ and 1.720(10) $\AA$ ) and nearlinear $\mathrm{C}-\mathrm{N}-\mathrm{Ti}$ bond angle $\left(175.9(2)^{\circ}\right.$ and $\left.172.4(9)^{\circ}\right)$. These indicate the effective electron donation to the metal from 
imidazolin-2-iminato moiety. Complexes 8 and 9 displayed a $172.8(4)^{\circ}$ in $\operatorname{Im}^{\text {Dipp } N T i C l M e} 2$ and $1.792(3) \AA-171.9(3)^{\circ}$ in short $\mathrm{Ti}-\mathrm{N}_{\text {imine }}$ bond distance and a larger $\mathrm{C}-\mathrm{N}-\mathrm{Ti}$ bond angle $\mathrm{Im}^{\text {Dipp }} \mathrm{NTiMe}_{3}$. Initially, it was found that titanium complexes

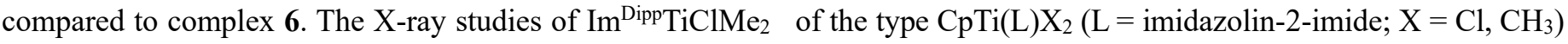
and $\mathrm{Im}^{\text {Dipp }} \mathrm{NTiMe}_{3}(\mathbf{1 0})$ complexes showed that with the were highly active for the polymerization of ethylene and coincrease in the number of methyl groups in the complex, the polymerization of ethylene with norbornene and 1-hexene. ${ }^{[61-}$ $\mathrm{Ti}-\mathrm{N}_{\text {imine }}$ bond distance increases, and the $\mathrm{C}-\mathrm{N}-\mathrm{Ti}$ bond angle 62] decreases. These bond parameters observed 1.762(4) $\AA-$

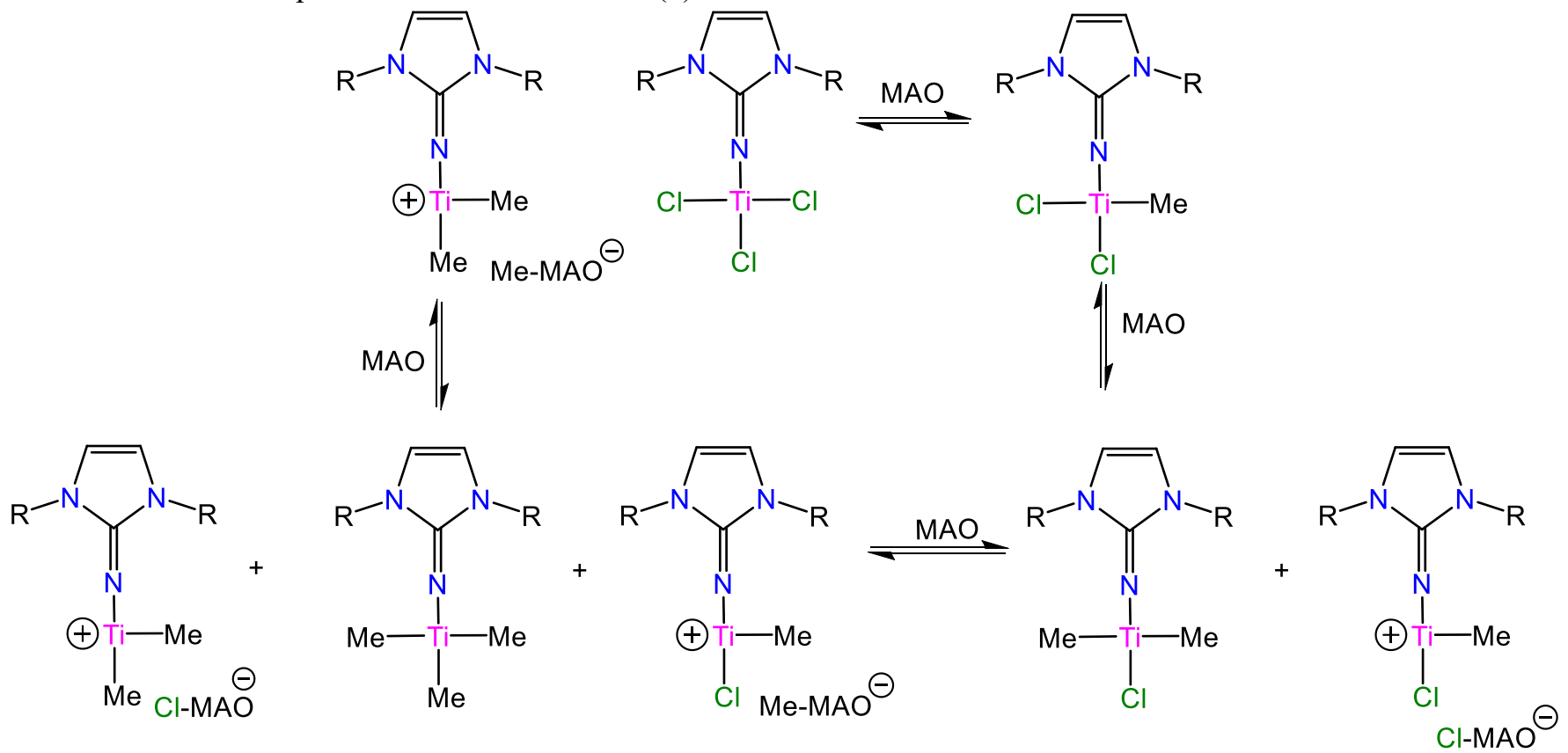

Scheme 6. Activation of $\mathrm{Im}^{\text {Dipp }} \mathrm{NTiCl}_{3}$ by MAO.

However, the complexes of type $\mathrm{L}_{2} \mathrm{TiX}_{2}(\mathrm{~L}=$ imidazolin2-imide; $\mathrm{X}=\mathrm{Cl}, \mathrm{CH}_{3}$ ) were found to be active in the living polymerization of propylene ${ }^{[63]}$ and motivated to employ the titanium complexes $\mathbf{8}, \mathbf{9}$, and corresponding methylated complexes $\mathbf{1 0}, \mathbf{1 1}$ for polymerization reactions of ethylene with the combination of methylaluminoxane (MAO) and trityltetrakis(pentafluorophenyl)-borate (TTPB). The PD of the obtained polymers at low ratios of MAO to $\mathbf{8}$ indicated the formation of more than one active species. The relatively higher Ti:Al ratios allowed the polymer formation with narrow PDs, attributed to the functioning of single-site catalysts. The molecular weight of the polymers varied with the amount of MAO used, and higher activity was achieved at $\mathrm{Al}: \mathrm{Ti}=100$. The methylated complexes were synthesized to get a better insight into the nature of active species at low MAO concentrations. The highly active $(\mathrm{Al}: \mathrm{Ti}=20)$ $\mathrm{Im}^{\text {Dipp }} \mathrm{NTiClMe}_{2}$ is assumed to be the first pre-catalyst intermediate formed with the reaction between $\mathrm{Im}^{\text {Dipp }} \mathrm{NTiCl}_{3}$ and MAO. The activity decreases with the increase of MAO quantity. Surprisingly, the best catalytic activity was achieved with $\mathrm{Im}^{\mathrm{Mes}} \mathrm{NTiCl}_{3}(\mathbf{9})$ at a very low Al:Ti ratio of 8 . The smaller cone angle was observed for $9\left(173.8^{\circ}\right)$ compared to other three complexes (i.e., $\mathrm{Im}^{\text {Dipp }} \mathrm{NTiCl}_{3}=259.0^{\circ}, \mathrm{Im}^{\text {Dipp NTiClMe }}{ }_{2}$ $=257.3^{\circ}$, and $\mathrm{Im}^{\text {Dipp }} \mathrm{NTiMe}_{3}=248.7^{\circ}$ ). The smaller cone angle is the direct manifestation for the relative higher reactivity of

9. The small cone angle implies a greater availability space for the incoming monomer unit. The formation of four possible active species were presumed based on the experimental results obtained with $\mathrm{Im}^{\mathrm{Dipp}} \mathrm{NTiCl}_{3}$ and low amounts of MAO: $\left[\mathrm{Im}^{\text {Dipp }} \mathrm{NTiClMe}^{+}[\mathrm{Cl}-\mathrm{MAO}]^{-},\left[\mathrm{Im}^{\text {Dipp }} \mathrm{NTiClMe}^{+}[\mathrm{Me}-\mathrm{MAO}]^{-}\right.\right.$ $\left.\left[\mathrm{Im}^{\text {Dipp NTiMe }}\right]_{2}\right]^{+}[\mathrm{Cl}-\mathrm{MAO}]^{-}$and $\left[\mathrm{Im}^{\text {Dipp NTiMe }}\right]^{+}[\mathrm{Me}-\mathrm{MAO}]^{-}$ It was also anticipated that the reaction between $\mathrm{Im}^{\text {Dipp }} \mathrm{NTiClMe}_{2}$ with MAO might produce the complexes

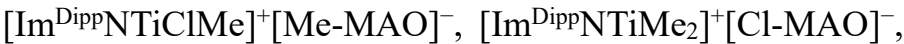
and $\left.\left[\operatorname{Im}^{\text {Dipp }}{ }^{\text {NTiMe }}\right]_{2}\right]^{+}[\mathrm{Me}-\mathrm{MAO}]^{-}$, while $\operatorname{Im}^{\text {Dipp }^{2}} \mathrm{NTiMe}_{3}$ can generate only $\left[\mathrm{Im}^{\text {Dipp }} \mathrm{NTiMe}_{2}\right]^{+}[\mathrm{Me}-\mathrm{MAO}]^{-}($Scheme 6$)$.
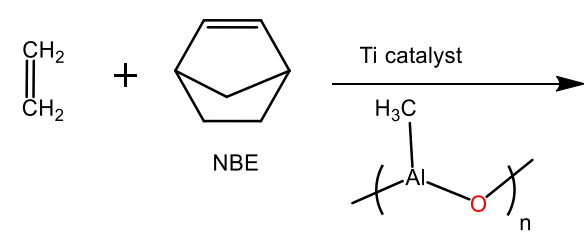

Scheme 7. Copolymerization of Ethylene/NBE by 6.

Tamm and co-workers investigated the ethylene/1-hexene co-polymerization behavior of complex $\mathbf{6}^{[64]}$ The difference in catalytic behavior was investigated by replacing cyclopentadienyl ligand with tropidinyl ligand. ${ }^{[65]}$ The copolymerizations reactions of ethylene/norbornene have been explored by the half-titanocene complex comprising of 
imidazolin-2-iminato ligands. ${ }^{[62]}$ Complex $\mathbf{6}$ exhibited remarkable performance affording copolymers with a high molecular weight with uniform distributions (Scheme 7).

Based on the proven analogy between imidazolin-2iminato and cyclopentadienyl ligands ${ }^{[52]}$ and the excellent ability of $\mathrm{Cp}^{\prime} \mathrm{Ti}(\mathrm{OAr}) \mathrm{X}_{2}$ as pre-catalyst in the olefin polymerization reaction, ${ }^{[57]}$ Eisen and co-workers synthesized numerous mixed imidazolin-2-iminato/aryl alkoxo Ti(IV) complexes. The complexes were prepared by treating different lithiated phenol with appropriate mono(imidazolin-2iminato)titanium trichloride complexes, and the catalytic performances were subsequently examined towards the polymerization of ethylene, propylene, 1-hexene, and 1octene. ${ }^{[66]}$

\subsubsection{Synthesis of titanium amido complex}

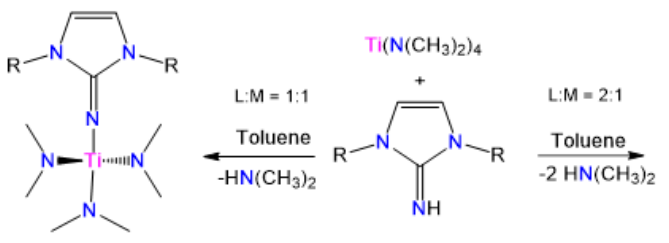

$\left[\mathrm{R}={ }^{\mathrm{t}} \mathrm{Bu}(17)\right]$ $[R=$ Mes (18)] $[R=\operatorname{Dipp}(19)]$

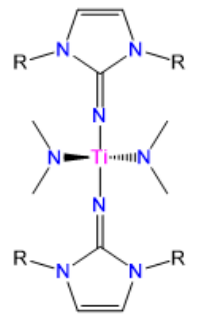

$\left[R={ }^{t} \mathrm{Bu}(15)\right]$ $[R=$ Mes (16)]
Scheme 8. Synthesis of bis/mono-imidazolin-2-iminato titanium (IV) amido complexes 15-19.

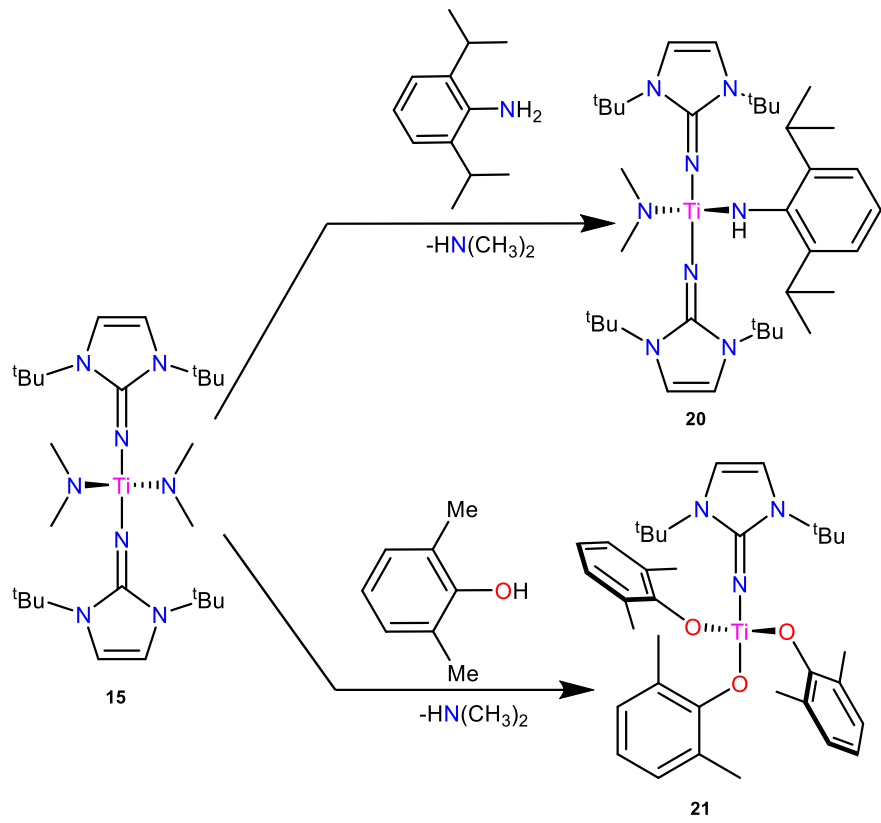

Scheme 9. Synthesis of $\mathbf{2 0}$ and $\mathbf{2 1 .}$

The 1:2 molar reaction between tetrakis(dimethylamido) titanium (IV) $\left[\mathrm{Ti}\left(\mathrm{N}\left(\mathrm{CH}_{3}\right)_{2}\right)_{4}\right]$ and imidazolin-2-imine $\left(\mathrm{Im}^{\mathrm{R}} \mathrm{NH}\right)$ ligands $\left[\mathrm{R}={ }^{t} \mathrm{Bu}(\mathbf{1 2})\right.$, Mes (13)] afforded bis-imidazolin-2iminato titanium (IV) complexes 15 and $16 \quad\left[k^{1}-\right.$ $\left.\left(\mathrm{Im}^{\mathrm{R}} \mathrm{N}\right)_{2} \mathrm{Ti}\left(\mathrm{N}\left(\mathrm{CH}_{3}\right)_{2}\right)_{2}\right]\left(\mathrm{R}={ }^{t} \mathrm{Bu}, 15 ; \mathrm{R}=\mathrm{Mes}, 16\right)$ in high yields (Scheme 8$)$. Similar reaction between metal and ligand
(12-14) maintaining 1:1 ratio afforded the mono-imidazolin2-iminato titanium (IV) complexes 17-19 [ $\mathrm{R}={ }^{t} \mathrm{Bu}(\mathbf{1 7})$, Mes (18), Dipp (19)]. ${ }^{[67]}$

Subsequent treatment of $\mathbf{1 5}$ with 2,6-diisopropylamine $\left(\mathrm{DippNH}_{2}\right)$ at $60^{\circ} \mathrm{C}$ afforded the corresponding mixed ligand titanium complex $\left[\kappa^{1}-\left(\operatorname{Im}^{t \mathrm{Bu}} \mathrm{N}\right)_{2} \mathrm{Ti}\left(\mathrm{NMe}_{2}\right)(\mathrm{HNDipp})\right]$ (20). ${ }^{[68]}$ However, identical reaction conditions with 2,6-diphenyl phenol afforded mono-imidazolin-2-iminato Ti(IV) phenolate complex $\left[\kappa^{1}-\left(\operatorname{Im}^{\mathrm{tBu}} \mathrm{N}\right) \mathrm{Ti}\left(\mathrm{O}-1,6-\mathrm{Me}_{2} \mathrm{C}_{6} \mathrm{H}_{3}\right)_{3}\right]$ (21) (Scheme 9).

The Ti- $\mathrm{N}_{\text {amide }}$ distances in complex 17 were slightly higher compared to complex 18 and 19. The Ti- $\mathrm{N}_{\text {iminato }}$ bond lengths in the complex 18 (1.851(1) $\AA$ ) and $19(1.853(1) \AA)$ are comparable, however, these distances found slightly longer compared to complex 17, presumably due to the positive inductive effect of tert-butyl groups enhanced the electron availability of ring $\mathrm{N}$-atom of imidazolin-2-iminato moiety [50,52]. In complex 17 and $\mathbf{1 9}$, the $\mathrm{Im}^{\mathrm{R}} \mathrm{N}^{-}$moiety coordinated to the metal ion in a nearly linear fashion $\left(\mathrm{Ti}-\mathrm{N}-\mathrm{C}=170.9^{\circ}\right.$ and $169.2(1)^{\circ}$, respectively), however, this angle significantly deviated from the linearity for the complex $\mathbf{1 8}\left(164.5(1)^{\circ}\right)$. The $\mathrm{Ti}-\mathrm{N}_{\text {iminato }}$ bond lengths in all complexes are observed slightly shorter $[1.847(2) \AA$ and $1.858(2) \AA$ for complex 16; $1.8242(18)$ $\AA$ and 1.8334(17) $\AA$ for complex 20 and 1.7738(16) $\AA$ for 21], compared to the previously reported complexes, indicating the strong $2 \sigma, 4 \pi$-electron donation of imidazolin-2-iminato moiety.

\subsubsection{The cyclization of amino acid esters mediated by $\mathrm{Ti}$ complex}

Quinazolinones, an imperative heterocyclic compound, have numerous biological applications ${ }^{[69-75]}$ and are used as a synthon for various natural products. ${ }^{[76-78]}$ It has been reported that quinazolinones can be synthesized by the reaction of halo benzoic acid and guanidine, catalyzed by $\mathrm{CuI}$. However, this method becomes unfavorable due to the requirement of a large number of additives. ${ }^{[79]}$ Panda and co-workers recently reported the hydroamination/cyclization of amino acid esters with carbodiimides and isocyanates to afford the corresponding quinazolinone and urea derivatives mediated by bis-imidazolin-2-iminato titanium(IV) amido complexes $\mathbf{1 5}$ or $\mathbf{1 6}$ (Scheme 10$){ }^{[80]}$

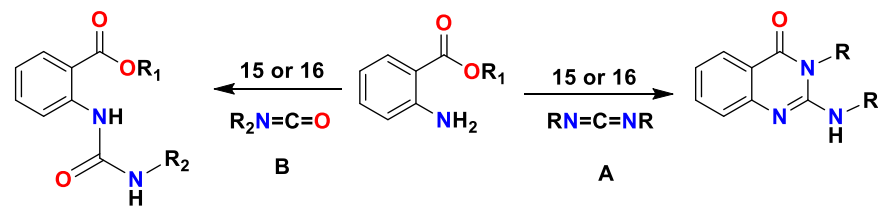

Scheme 10. Catalytic cyclization (A) and guanylation (B) of amino acid esters with carbodiimides and isocyanates respectively. 


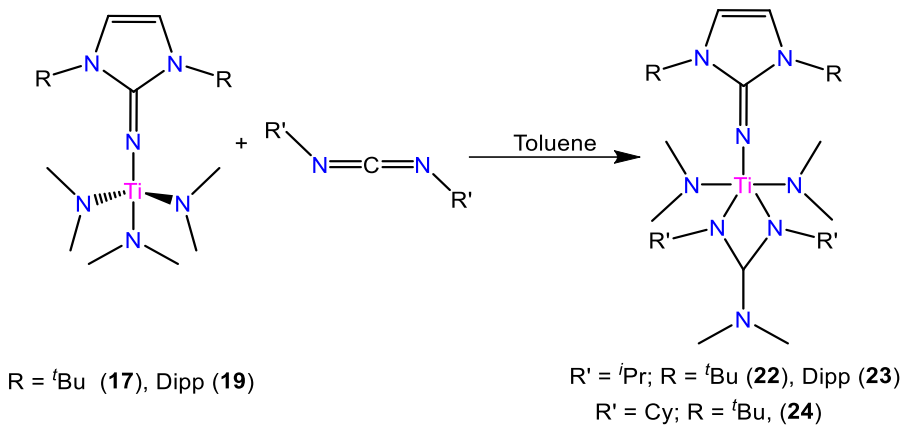

Scheme 11. Synthesis of titanium complexes 22, 23 and 24.

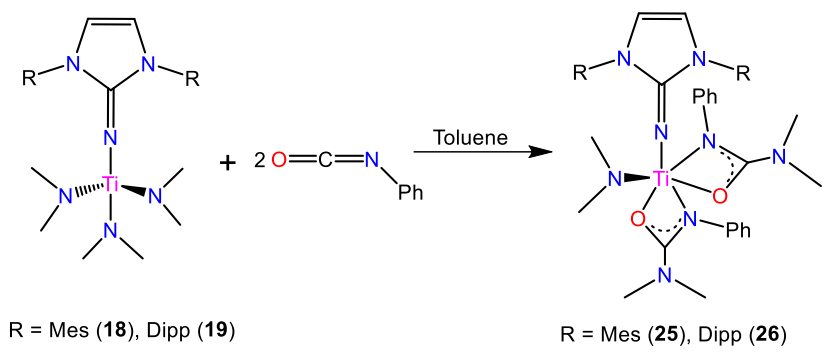

Scheme 12. Synthesis of Titanium complexes 25 and 26.

The stoichiometric reaction between mono imidazolin-2iminato titanium (IV) complexes (17 and 19) with $\mathrm{N}, \mathrm{N}^{\prime}$ diisopropylcarbodiimide, and $\mathrm{N}, \mathrm{N}^{\prime}$-dicyclohexylcarbodiimide afforded corresponding mono inserted titanium guanidinate complexes 22-24 in good yields (Scheme 11). ${ }^{[81]}$ Further insertion products were not traced even in presence of excess carbodiimides, presumably attributed to the absence of free coordination site on complex $\mathbf{2 4}$ and the lower electrophilicity of the sp-carbon of carbodiimide molecule. Exclusive formation of the bis-inserted compound as the sole reaction product upon the treatment of 1:1 or 1:2 molar ratio of the metal complex and $\mathrm{PhNCO}$ indicated the higher reactivity of isocyanate compared to carbodiimide towards metal complexes 18 and 19.

The complex 18 was exploited towards the catalytic addition of an amine to phenyl isocyanate and carbodiimide to afford corresponding urea and guanidine, respectively. The catalytic cycle started with the attack of metal coordinated $\mathrm{NMe}_{2}$ of the pre-catalyst 19 to incoming phenyl isocyanate (PhNCO) to generate the complex 27 (Scheme 13). The second step involved the reaction between 2 equivalent incoming amines to form the corresponding titanium amido complex 28. Subsequently, 28 was converted to ureate 29 upon the treatment of 2 equivalent PhNCO. The catalytic cycle terminated with the reaction between the two equivalent amines and 29 to eliminate urea and regenerate the active species 28.

\subsection{Zirconium Complex}

Zirconium is the second most explored metal and has been used as a pre-catalyst for polymerization reactions. The Imidazolin-2-iminato is the ideal candidate for stabilizing high oxidation state metal and has been used as a spectator ligand for $\mathrm{Zr}(\mathrm{IV}){ }^{\left[{ }^{[2]}\right]}$ The Dipp substituted ligand ( $\left.\mathrm{Im}^{\text {Dipp }} \mathrm{NH}\right)$ was preferred for the study since its higher sterical encumbrance nature restricted the formation of the dinuclear complex and thus provided the stability of the mononuclear complex $\left[\left(\eta^{7}-\right.\right.$ $\left.\left.\mathrm{C}_{7} \mathrm{H}_{7}\right) \mathrm{Zr}\left(\mathrm{Im}^{\text {Dipp }} \mathrm{N}\right)\right]$. Tamm and co-workers used $\left[\left(\eta^{7}-\right.\right.$ $\left.\mathrm{C}_{7} \mathrm{H}_{7}\right) \mathrm{ZrCl}($ tmeda) $]$ (tmeda $=\mathrm{N}, \mathrm{N}, \mathrm{N}^{\prime}, \mathrm{N}^{\prime}$-tetramethylethylenediamine) as $\mathrm{Zr}$ metal precursor as it allowed for the smooth incorporation of pentadienyl, ${ }^{[83-85]}$ cyclopentadienyl, ${ }^{[86]}$ and phospholyl ligands. ${ }^{\left[{ }^{87-89]}\right.}$ The first $\mathrm{Zr}$ complex bearing imidazolin-2-iminato was synthesized by reacting lithium salt of 14 with $\left[\left(\eta^{7}-\mathrm{C}_{7} \mathrm{H}_{7}\right) \mathrm{ZrCl}(\right.$ tmeda $\left.)\right]$ (Scheme 14). The complex 30 exhibited slightly longer $\mathrm{Zr}-\mathrm{N}$ bond distance $(2.5136(14)$ and $2.5737(13) \AA$ ) than the starting material $(2.477(2) /$ $2.519(2) \AA)$.

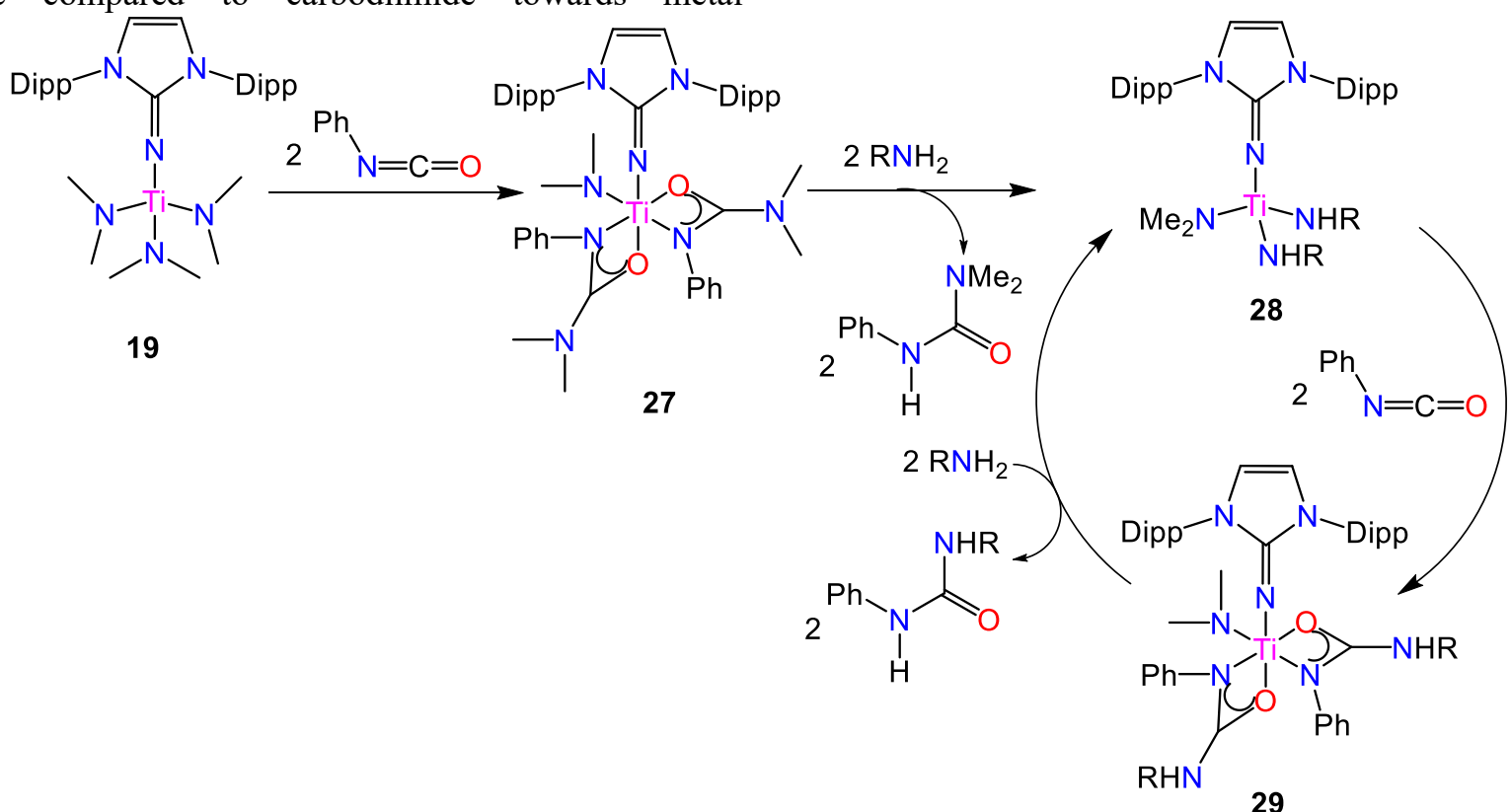

Scheme 13. A plausible mechanism for the catalytic addition of $\mathrm{N}-\mathrm{H}$ bond to isocyanate by titanium precatalyst 19 . 
In the ${ }^{1} \mathrm{H}$ NMR spectrum, 30 exhibited a singlet at 4.82 ppm characteristics to $\mathrm{C}_{7} \mathrm{H}_{7}$ ligand. The acid-base reaction between imidazolin-2-imine and rare-earth-metal neosilyl complexes found an expedient method for incorporation of imidazolin-2-iminato into the metal coordination sphere. The tmeda-free $\mathrm{Zr}$ complex $\left[\left(\eta^{7}-\mathrm{C}_{7} \mathrm{H}_{7}\right) \mathrm{Zr}\left\{\eta^{3}-\mathrm{C}_{3} \mathrm{H}_{3}(\mathrm{TMS})_{2}\right\}\right.$ (THF)] (31) was synthesized by treating $\left[\left(\eta^{7}-\mathrm{C}_{7} \mathrm{H}_{7}\right) \mathrm{ZrCl}(\right.$ tmeda $\left.)\right]$ and $\mathrm{K}\left[\mathrm{C}_{3} \mathrm{H}_{3}(\mathrm{TMS})_{2}\right]$ in THF. Subsequent treatment of $\mathbf{3 1}$ and $\mathbf{1 4}$ in 1:1 ratio afforded the $\left[\left(\eta^{7}-\mathrm{C}_{7} \mathrm{H}_{7}\right) \mathrm{Zr}\left(\mathrm{Im}^{\text {Dipp }} \mathrm{N}\right)\right]$ (32) (Scheme 15), which acted as an initiator for the ring-opening polymerization of $\varepsilon$-caprolactone (Scheme 16). Complex 32 displayed pogo stick geometry identical to $\left[\left(\eta^{8}-\mathrm{C}_{8} \mathrm{H}_{8}\right) \mathrm{Ti}(\mathrm{NR})\right]$ complexes. ${ }^{[90]}$ The reaction followed the coordination insertion mechanism, in which $\varepsilon$-caprolactone was first coordinated to the metal. Subsequently, the nucleophilic attack of imidazolin2 -iminato to the carbon atom of the $\mathrm{C}=\mathrm{O}$ group released the ring strain upon ring-opening. The presence of bulky Dipp substituents and cycloheptatrienyl ring in complex $\mathbf{3 2}$ inhibited the dimerization process. ${ }^{[91]}$

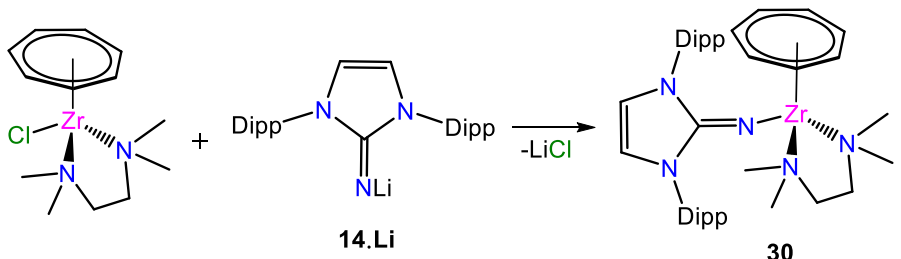

Scheme 14. Synthesis of complex $\left[\left(\eta^{7}-\mathrm{C}_{7} \mathrm{H}_{7}\right) \mathrm{Zr}\left(\operatorname{Im}^{\text {Dipp }} \mathrm{N}\right)(\right.$ tmeda $\left.)\right]$ (30).

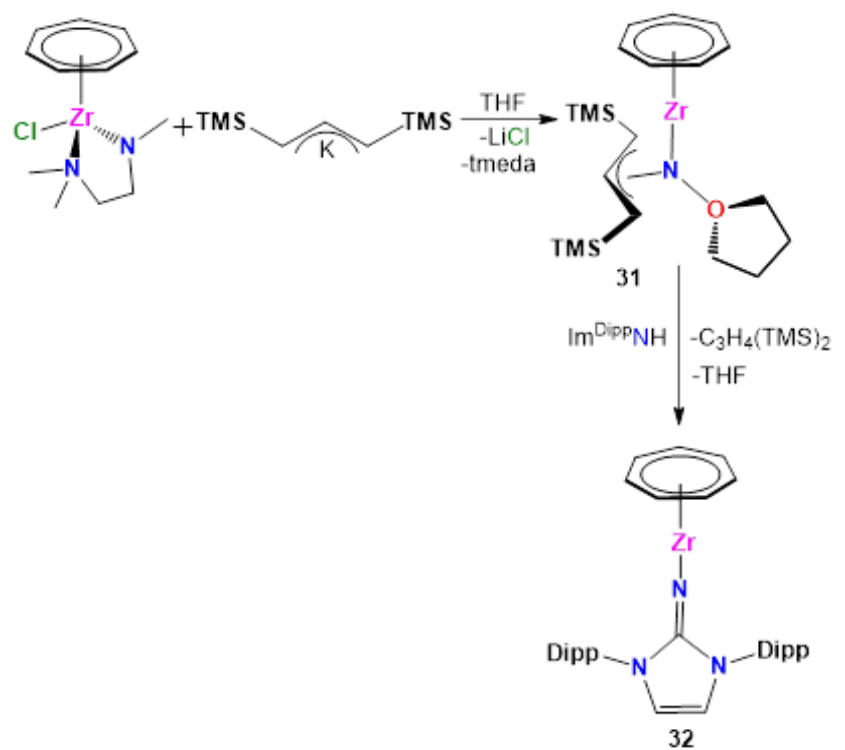

Scheme 15. Synthesis of $\mathbf{3 1}$ and $\mathbf{3 2}$.

\subsection{Hafnium complex}

According to the recently maiden report, the Hf complex comprises of imidazolin-2-iminato moiety. ${ }^{[92]}$ The uniqueness of Hf amongst the electrophilic group 4 is its highest oxophilicity and unusual small size due to lanthanide contraction. ${ }^{[93]}$ The mono-(imidazolin-2-iminato)hafnium (IV) complexes 33-34 were prepared by reacting imidazolin-2imine ligands (12 and 14) and hafnium-tetra benzyl complex in equimolar ratios (Scheme 17). The $\mathrm{Hf}-\mathrm{N}$ bond distance in complex 33 (1.924(6) $\AA$ ) found slightly longer than complex 34 (1.911(5) \&). The near-linear disposition of $\mathrm{Hf}-\mathrm{N}-\mathrm{C}$ was observed in $33\left(176.2(3)^{\circ}\right)$ and $\mathbf{3 4}\left(172.2(3)^{\circ}\right)$. The observed smaller cone angle for complex $33\left(124^{\circ}\right)$ compared to $\mathbf{3 4}$ $\left(262^{\circ}\right)$ implies the greater accessible space for incoming substrates to complex $\mathbf{3 3}$.

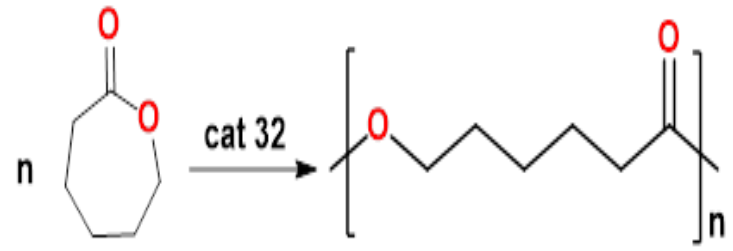

Scheme 16. Polymerization of $\varepsilon$-CL using complex 32 as a catalyst.

The activities of $\mathrm{Hf}$ complexes $\mathbf{3 3}$ and $\mathbf{3 4}$ were investigated towards the hydroboration of a wide range of numerous aldehydes, ketones, and carbodiimides. The aldehyde containing electron-withdrawing groups proceeded at a faster rate than aldehydes with electron-donating groups. Both the complexes showed excellent chemoselectivity where the carbonyl group was selectively hydroborated, leaving other functionalities unchanged. A plausible mechanism was proposed for the carbonyl hydroboration reaction (Scheme 18).

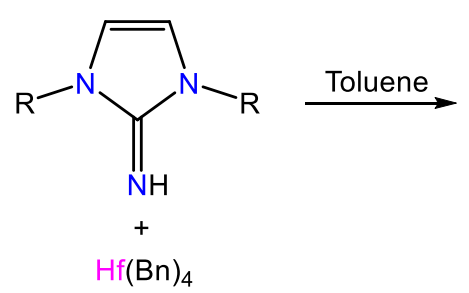

$\left[\mathrm{R}={ }^{t} \mathrm{Bu}(12)\right]$

[R = Dipp (14)]

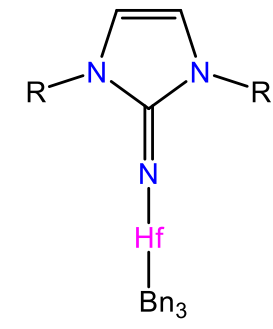

33: $\mathrm{R}={ }^{t} \mathrm{Bu}$

34: $R=\operatorname{Dipp}$
Scheme 17 Synthesis of mono imidazolin-2-iminato Hf (IV) complexes 33 and 34.

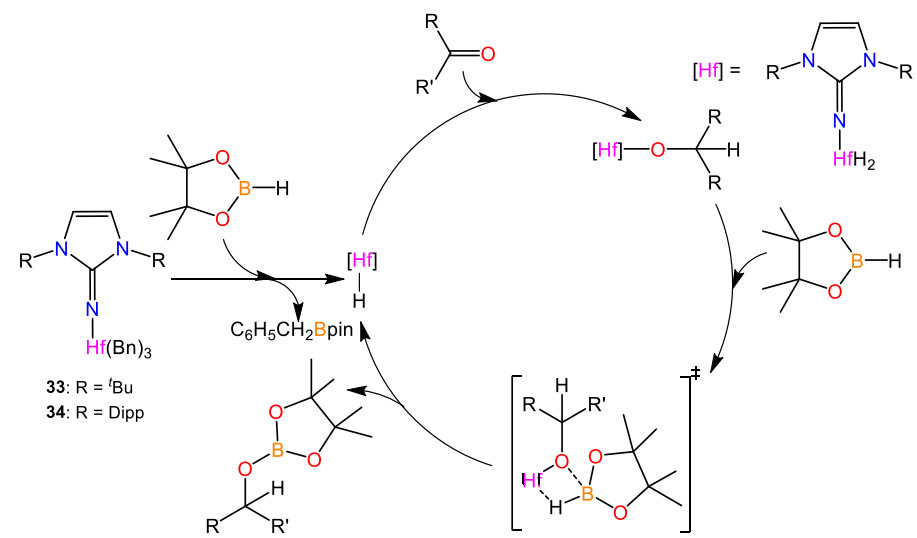

Scheme 18 Proposed mechanism for hydroboration of $\mathrm{C}=\mathrm{O}$ promoted by the $\mathbf{3 3}$ and $\mathbf{3 4}$.

The catalytic cycle for hydroboration of carbonyl substrates started with the generation of trihydride species by the rapid reaction between the hafnium pre-catalysts $\mathbf{3 3 / 3 4}$ and 
HBpin. The second step involved the insertion of the incoming aldehyde/ketone substrates into one of the metal-hydride bonds to produce the hafnium alkoxide. Subsequently, metal alkoxide species reacted with another incoming HBpin to form the hydroborated products with the concomitant regeneration of active hydride species.

\subsection{Vanadium Complex}<smiles>[R]n1ccn([R])c1=NC(C)(C)N(CC)C12CC3CC(CC(C3)C1)C2</smiles>

35

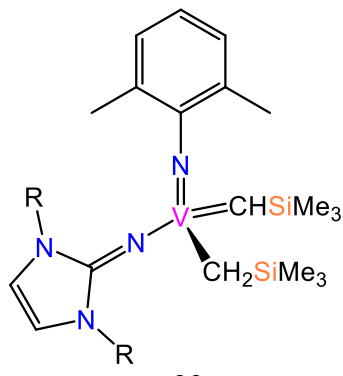

36

$$
\mathrm{R}=2,6-{ }^{i} \mathrm{Pr}_{2} \mathrm{C}_{6} \mathrm{H}_{3}
$$

Chart 1. Molecular structure of $\mathbf{3 5}$ and $\mathbf{3 6}$.<smiles>Cc1cccc(C)c1N=[V](Cl)(Cl)Cl</smiles>

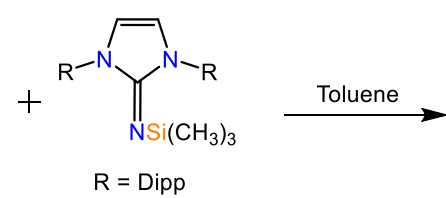

$2 e$

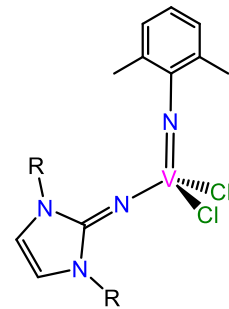

37
Scheme 19. Synthesis of 37.

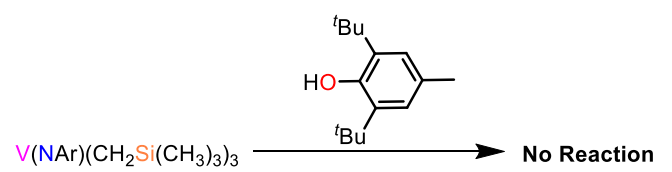

$$
\text { ArOH n-hexane }
$$
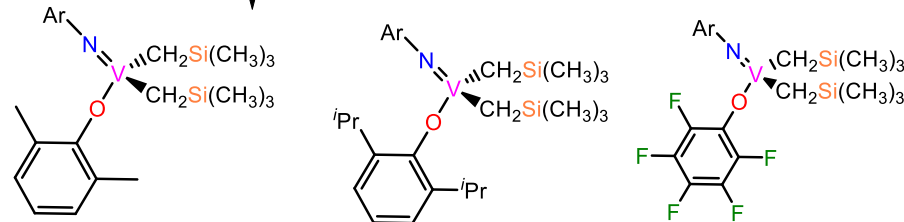

$\mathrm{Ar}=2,6-\mathrm{Me}_{2} \mathrm{C}_{6} \mathrm{H}_{3}$

Scheme 20. Schematic presentation of reaction between (arylimido)vanadium(V) trialkyl and aryl alcohols.

Recently (Imido)vanadium(V) complexes received considerable attention due to their unique characteristics of resemblance to the popular olefin polymerization catalysts. Besides olefin polymerization reactions, (Imido)vanadium(V) complexes containing imidazolin-2-iminato (35 and $\mathbf{3 6}$ ) have been known as the promising candidates for ROMP of cyclic olefins (Chart 1).${ }^{[94-97]}$ Recently, Nomura et al. synthesized a series of (imido)vanadium(V) dichloride complexes containing imidazolin-2-iminato ligands. The (N-2,6-
$\left.\mathrm{Me}_{2} \mathrm{C}_{6} \mathrm{H}_{3}\right)$ vanadium(V) dichloride complexes 37 bearing $\mathrm{Im}^{\mathrm{Dipp}} \mathrm{N}$ ligand was synthesized by reacting $\mathrm{V}(\mathrm{N}-2$,6$\left.\mathrm{Me}_{2} \mathrm{C}_{6} \mathrm{H}_{3}\right) \mathrm{Cl}_{3}$ with $2 \mathrm{e}$ in toluene for six hours (Scheme 19).

The $\left(\operatorname{Im}^{\text {Dipp }} \mathrm{N}\right)(\mathrm{NAd})$ vanadium(V) dichloride (38) and $\left(\mathrm{Im}^{\mathrm{Dipp}} \mathrm{N}\right)(\mathrm{NPh})$ vanadium $(\mathrm{V})$ dichloride (37) were synthesized following similar reaction conditions by treating $\mathrm{V}(\mathrm{NAd}) \mathrm{Cl}_{3}$ or $\mathrm{V}(\mathrm{NPh}) \mathrm{Cl}_{3}{ }^{[98]}$ with 2e. All the complexes were employed as pre-catalysts for ethylene polymerization and ethylene/ norbornene copolymerization using $\mathrm{Et}_{2} \mathrm{AlCl}$ as cocatalyst. ${ }^{[99]}$ The calculated chemical shifts obtained by the GIAO-DFT method well agree with the experimental ${ }^{51} \mathrm{~V}$ NMR chemical shifts value. ${ }^{[94]}$ Various vanadium(V)-alkyls complexes were synthesized by reacting (arylimido)vanadium(V) trialkyl analogue, $\mathrm{V}(\mathrm{NAr})\left(\mathrm{CH}_{2} \mathrm{SiMe}_{3}\right)_{3}\left(\mathrm{Ar}=2,6-\mathrm{Me}_{2} \mathrm{C}_{6} \mathrm{H}_{3}\right)$ and substituted phenols/alcohols in unimolar ratio. However similar reaction didn't proceed with bulky $2,6-{ }^{t} \mathrm{Bu}_{2}-4-$ $\mathrm{MeC}_{6} \mathrm{H}_{2} \mathrm{OH}$ even with the use of excess amount (Scheme 20).

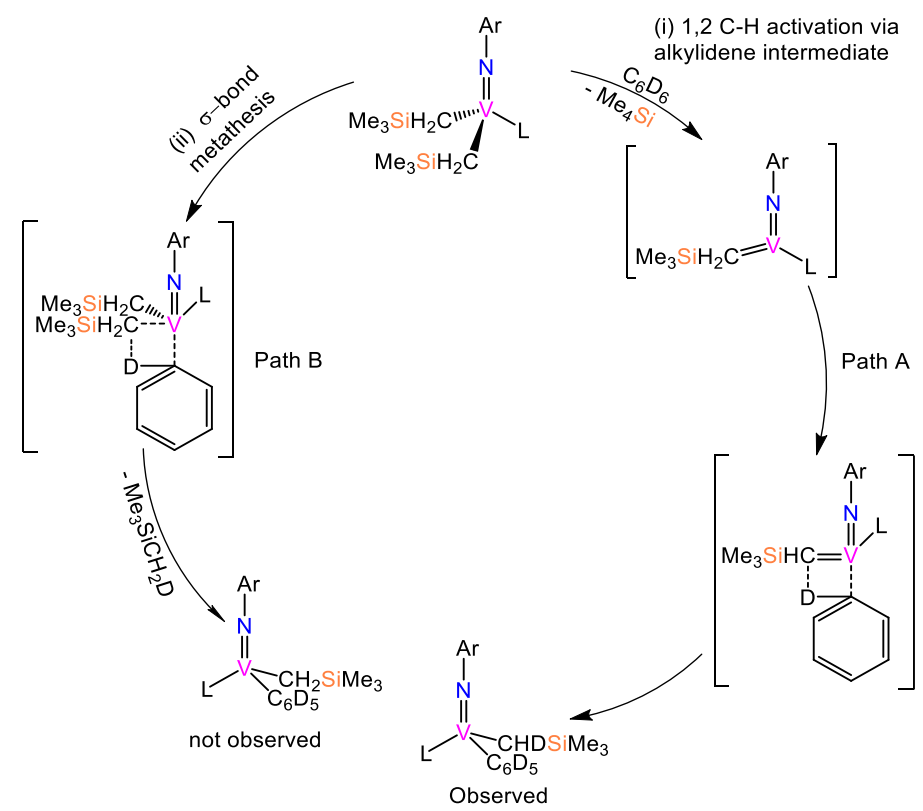

Scheme 21. The probable mechanism for the formation of the phenyl complexes.

Further, Nomura et al. studied 1,2-C-H/D activation of benzene $/ \mathrm{C}_{6} \mathrm{D}_{6}$ mediated by (arylimido)vanadium(V)alkylidene complexes. Two possible mechanisms were suggested for the process: (1) 1,2 C-D activation; and (2) $\sigma$ bond metathesis (Scheme 21). The formation of $\mathrm{CHDSiMe}_{3}$ was confirmed by the ${ }^{2} \mathrm{H}$ NMR spectrum $\left(\delta=2.10 \mathrm{ppm}, \mathrm{d}, \mathrm{J}_{\mathrm{DH}}\right.$ $=40 \mathrm{~Hz}$ ). However, the nonexistence of $\mathrm{CD}_{2} \mathrm{SiMe}_{3}$ and $\mathrm{CH}_{2} \mathrm{SiMe}_{3}$ were confirmed by the ${ }^{2} \mathrm{H}$ NMR spectrum and ${ }^{1} \mathrm{H}$ NMR spectrum, respectively. The above data is strongly supportive of path A that involved the 1,2-C-D bond activation of $\mathrm{C}_{6} \mathrm{D}_{6}$ via the vanadium $(\mathrm{V})$-alkylidene intermediate.

\subsection{Tungsten and molybdenum complexes}

Alkene/alkyne metathesis has a substantial influence on modern petrochemical and polymer industries. Highoxidation-state tungsten and molybdenum complexes containing alkylidene and alkylidyne ligands are well known 
to catalyze the olefin metathesis reactions. ${ }^{[100-104]}$ For example, Tamm and co-workers contributed to this field by reporting first tungsten and molybdenum alkylidyne complexes bearing strongly electron-donating imidazolin-2-iminato ligands in combination with electron-withdrawing fluorinated alkoxides. ${ }^{[105-106]}$ The reactions between the trialkoxides alkylidyne precursors 39 with lithium salt of imidazolin-2imides at room temperature conveniently afforded the metal complexes 40 (Scheme 22). Most of the complexes (except 40b) showed excellent activities for ring-closing alkyne metathesis (RCAM) and alkyne cross-metathesis (ACM) reactions.

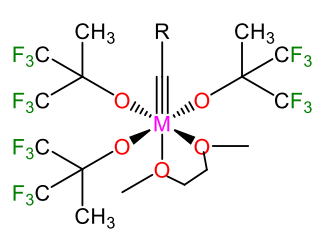

39a: $M=W, R={ }^{t} B u$ 39b: $M=M O R=P h$
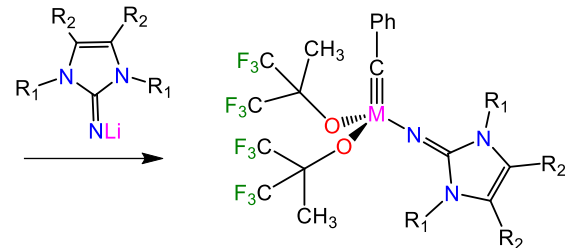

40a: $M=W, R={ }^{t} B u, R_{1}={ }^{t} B u, R_{2}=H$ 40b: $M=W, R={ }^{t} B u, R_{1}=$ Dipp, $R_{2}=H$ 40c: $M=W, R=P h, R_{1}={ }^{t} B u, R_{2}=H$ 40d: $M=M o, R=P h, R_{1}={ }^{t} B u, R_{2}=H$ 40e: $M=W, R=P h, R_{1}={ }^{t} B u, R_{2}=M e$

Scheme 22. Synthesis of 40.

Recently, Basset and co-workers elaborately demonstrated a synthetic approach for the preparation of a functionalized silica-supported tungsten oxo complex $[(\equiv \mathrm{Si}-\mathrm{O}-) \mathrm{W}(=\mathrm{O})$ $\left.\left(\mathrm{CH}_{3}\right)_{2}-\mathrm{L}\right], \mathrm{L}=\mathrm{Im}^{\text {Dipp }} \mathrm{N}^{\left[{ }^{[107]}\right.}$ The reaction between tungsten (VI) oxytetrachloride and 1 equivalent $\mathrm{N}$-silylated 2iminoimidazoline in dichloromethane under the refluxing condition afforded the rapid precipitation of complex $\mathrm{Im}^{\text {Dipp }} \mathrm{NWOCl}_{3}(41)$ as the orange crystalline solid in high yield (84\%) (Scheme 23).

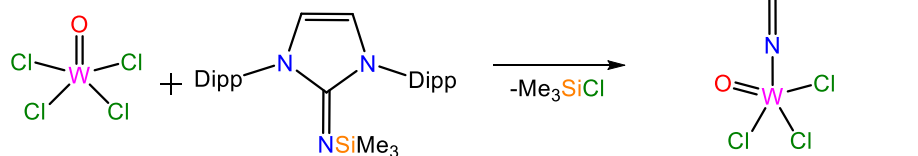

$2 \mathrm{e}$

41

Scheme 23. Synthesis of $\operatorname{Im}^{\text {Dipp }} \mathrm{NWOCl}_{3}(\mathbf{4 1})$.

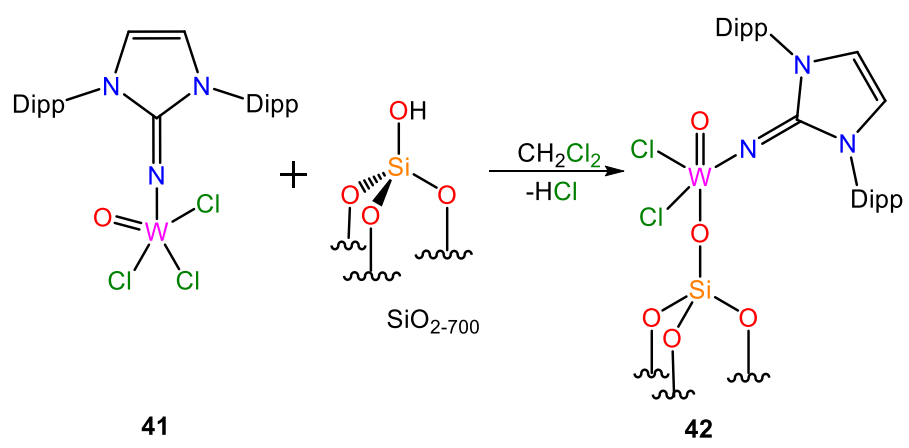

Scheme 24. Synthesis of $\left[(\equiv \mathrm{Si}-\mathrm{O}-) \mathrm{W}(=\mathrm{O}) \mathrm{Cl}_{2}-\mathrm{Im}^{\mathrm{Dipp}} \mathrm{N}\right](\mathbf{4 2})$.

The pronounced shifting of backbone $\mathrm{H}$ of imidazolin-2iminato ring in the downfield region of the ${ }^{1} \mathrm{H}$ NMR spectrum confirmed the desilylation and coordination of the nitrogen to the metal center. The HSQC ${ }^{1} \mathrm{H},{ }^{13} \mathrm{C}$ correlation NMR spectra also support the structure of compound 41 . The $\mathrm{W}-\mathrm{N}$ bond distance in 41 (1.782(5)) $\AA$ is consistent with other related tungsten complexes $\left[\mathrm{Me}_{3} \mathrm{CCH}=\mathrm{W}\left(\mathrm{N}^{\mathrm{Dipp}}\right)\left(\mathrm{OCCMe}_{3}\right)_{2}\right]^{[108]}$ $(1.731(6), 1.748(6) \AA)$ and $\left[\mathrm{PhCH}=\mathrm{W}\left(\mathrm{N}^{\mathrm{Dipp}}\right)\left\{\mathrm{OCMe}\left(\mathrm{CF}_{3}\right)_{2}\right\}_{2}\right]$ $(1.708(17) \AA) .^{[109]}$ The W-Cl bond length $(2.36 \AA)$ is also compared with related bis(2,4,6-tribromophenoxy) tungsten(VI) oxychloride complex $(2.3104(13)-2.3302(13)$ $\AA)^{[110]}$. The $\mathrm{W}=\mathrm{O}$ bond length in $41(1.729(5) \AA)$ is slightly larger than related tungsten complex $\mathrm{W}(\mathrm{O})(\mathrm{CH}-t$ $\mathrm{Bu})\left[\mathrm{N}\left(\mathrm{C}_{6} \mathrm{~F}_{5}\right)_{2}(\mathrm{OHMT})\left(\mathrm{PMe}_{2} \mathrm{Ph}\right)(1.710(2) \AA, \mathrm{HMTO}=2,6-\right.$ dimesityl phenoxide). ${ }^{[111]}$ The characteristic stretching bands at 946 and $360 \mathrm{~cm}^{-1}$ in Raman spectroscopy are attributed to the $\mathrm{W}=\mathrm{O}$ and the $\mathrm{W}-\mathrm{Cl}$ bond vibrations, respectively.

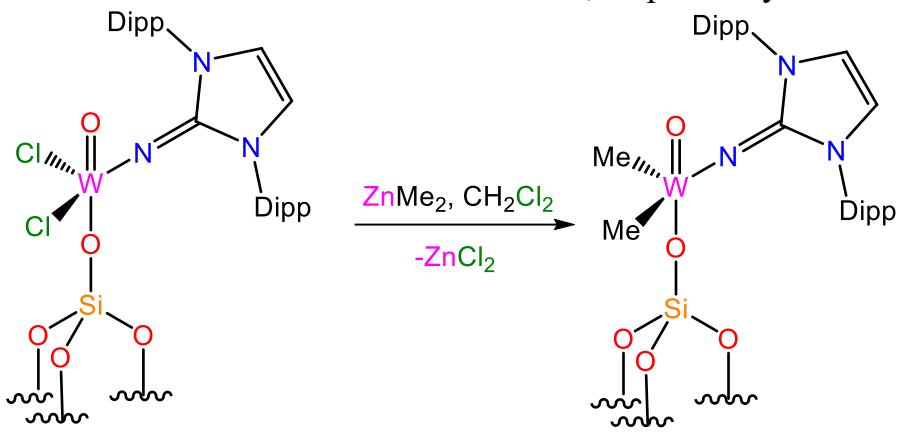

42

43

Scheme 25. Synthesis of $\left[(\equiv \mathrm{Si}-\mathrm{O}-) \mathrm{W}(=\mathrm{O}) \mathrm{Me}_{2}-\mathrm{Im}^{\mathrm{Dipp}} \mathrm{N}\right](\mathbf{4 3})$.

The surface compound $\left[(=\mathrm{Si}-\mathrm{O}-) \mathrm{W}(=\mathrm{O}) \mathrm{Cl}_{2}-\mathrm{Im}^{\text {Dipp }} \mathrm{N}\right](\mathbf{4 2})$ was synthesized by grafting of $\mathbf{4 1}$ on partially dehydroxylated silica at $700{ }^{\circ} \mathrm{C}$ (Scheme 24). The reaction was carried out under mild dynamic vacuum conditions to eliminate gaseous $\mathrm{HCl}$ produced during the reaction. The molecular complex $\mathbf{4 2}$ was collected as a light orange solid by washing with dichloromethane. The complete disappearance of the hydroxyl peak at $3745 \mathrm{~cm}^{-1}$ in the IR spectra indicated the total consumption of surface silanols.

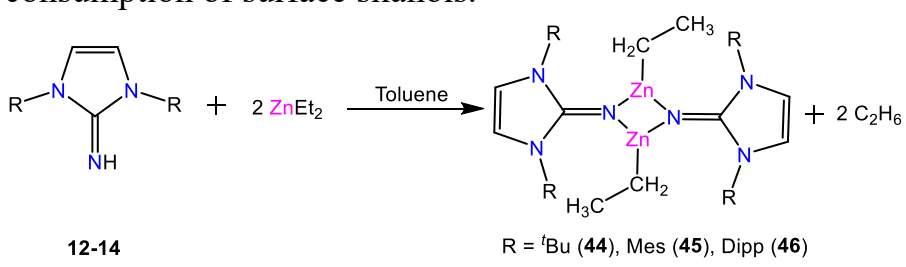

Scheme 26. Synthesis of $\mathrm{Im}^{\mathrm{R}} \mathrm{NZn}$ complexes 44-46.

The compound 42 was further alkylated with $\mathrm{ZnMe}_{2}$ to form $\left[(\equiv \mathrm{Si}-\mathrm{O}-) \mathrm{W}(=\mathrm{O}) \mathrm{Me}_{2}-\mathrm{Im}^{\text {Dipp }} \mathrm{N}\right]$ (43) (Scheme 25$)$. A close look at the FT-IR spectrum of $\mathbf{4 3}$ revealed that a substantial shift for $v(\mathrm{C}=\mathrm{N})$ band was observed to $1612 \mathrm{~cm}^{-1}$ (vs. 1653 $\mathrm{cm}^{-1}$ in 42), which clearly indicated the alteration in the electronic environment around the central metal.

The catalytic utility of $\mathbf{4 2}$ was explored towards the metathesis of terminal olefins like propene and 1-hexene. Under the condition of temperature $150{ }^{\circ} \mathrm{C}$, the metathesis reaction of propene produced an equilibrated mixture of 
ethane/2-butenes with TON 1165. The tungsten complex 43 found to be more selective toward the formation of dec-5-ene than other tungsten-based catalysts.

\subsection{Zinc complex}

In recent years, the first-row transition metal compounds have emerged as a homogeneous catalyst in the field of organometallic chemistry and catalysis, which were conventionally the realm of precious metal. Recently there is a growing interest in the potential replacement of precious metals with $3 \mathrm{~d}$ metals, which are less environmentally harmful, low cost, and highly abundant. However, the performance of the base metal catalysts always lacked behind the noble metal catalysts. Therefore, suitably designed ligand systems might be an enabling methodology to enhance the aptitude of the base metal catalysts. Although the aptitude of organozinc compounds was established in numerous catalytic reactions like the Reformatskii reaction, ${ }^{[12-115]}$ Negishi reaction, ${ }^{[116-118]}$ Fukuyama reaction, ${ }^{[119-124]}$ etc. it is still to explore catalytic borylation. Recently, $\mathrm{Zn}(\mathrm{II})$ complexes bearing different $\operatorname{Im}^{\mathrm{R}} \mathrm{N}^{-}$and analogous benzimidazolin-2-iminato ligands have been reported. ${ }^{[125-126]}$

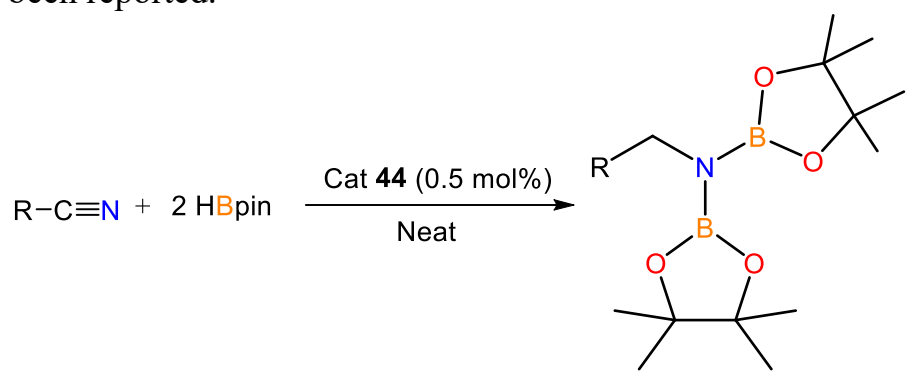

Scheme 27. Organozinc (44) catalyzed hydroboration of nitriles with HBpin.

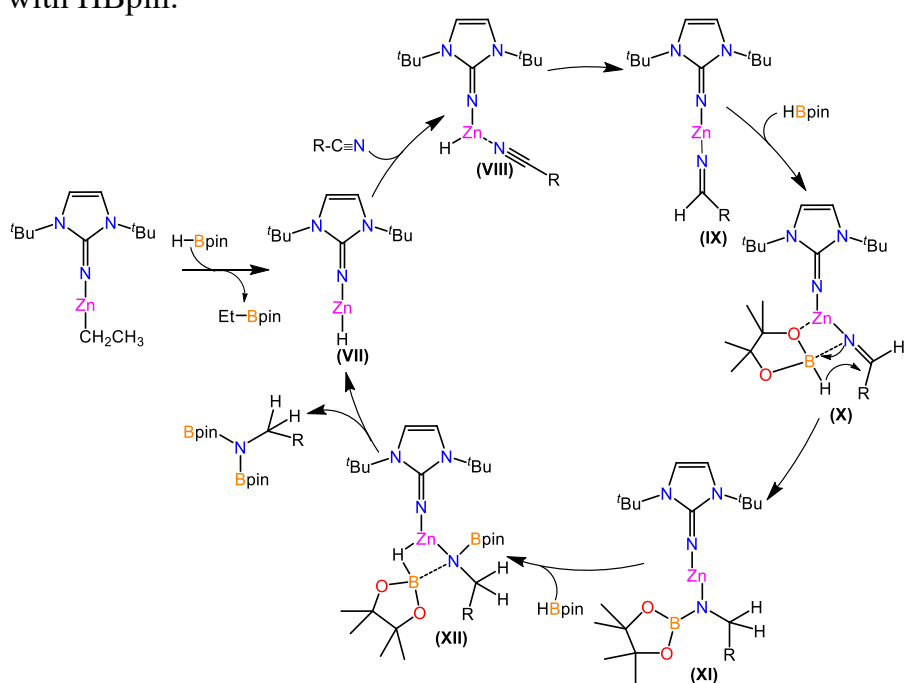

Scheme 28. The plausible mechanism for catalytic hydroboration of organic nitriles mediated by 44 .

The $\mathrm{Zn}$ complexes were conveniently synthesized by reacting diethylzinc $\left(\mathrm{ZnEt}_{2}\right)$ with $\mathrm{Im}^{\mathrm{R}} \mathrm{NH}$ in equimolar ratios (Scheme 26). The ${ }^{1} \mathrm{H}$ NMR spectra of $\mathbf{4 4}$ and $\mathbf{4 6}$ exhibit quartet signals at $\delta_{\mathrm{H}}-0.71$ and $-0.46 \mathrm{ppm}$, which are attributed to methylene protons of respective complexes. In contrast, complex 45 displayed two different quartet signals at $\delta_{\mathrm{H}} 0.02$ and $-0.53 \mathrm{ppm}$ for each of the $\mathrm{CH}_{2}$ protons. The methyl protons of ethyl groups of the complexes $\mathbf{4 4}$ and $\mathbf{4 6}$ appeared as a triplet at $\delta_{\mathrm{H}} 1.58$ and $1.26 \mathrm{ppm}$, respectively. The molecular structure of 45 was confirmed by single-crystal Xray diffraction analysis, which revealed that the geometry of central metal is distorted trigonal planar with the shortest $\mathrm{Zn}$ $\mathrm{N}$ distance $(1.974(2) \AA)$ reported so far. ${ }^{[127-129]}$ All the $\mathrm{Zn}$ complexes (44-46) were employed for catalytic hydroboration of different aliphatic and aromatic organic nitriles, and $\mathbf{4 4}$ amongst all was found most active in the series (Scheme 27). All the complexes displayed excellent tolerance for hydroborations of various electron-deficient and electron-rich organic nitriles and achieved desired diborylamine products within $12-24 \mathrm{~h}$.

The compound $\mathbf{4 4}$ also exhibited chemoselectivity in the presence of other functionalities (nitro and ester). However, the use of 4-formylbenzonitrile and 4-acetylbenzonitrile resulted in hydroboration to both nitrile and aldehyde/ketone functionalities. A plausible reaction was proposed based on the experimental results (Scheme 28). The catalytic cycle started with the reaction between pre-catalyst $\mathbf{4 4}$ and HBpin to form the active metal hydride species (VII). Subsequently, incoming nitrile coordinated to metal to give species (VIII), followed by nitrile reduction, affording the $\mathrm{Zn}$-iminium intermediate (IX). The next step involved the $\sigma$-bond metathesis between iminium intermediate and HBpin to yield a four-membered species $(\mathbf{X})$, which underwent rearrangement to give monoboronate ester (XI). Afterward, the monoboronate ester reacted with the second molecule of incoming HBpin affording the species (XII), followed by the rearrangement of VI to the desired diborylamine product, along with regeneration of metal hydride species VII.

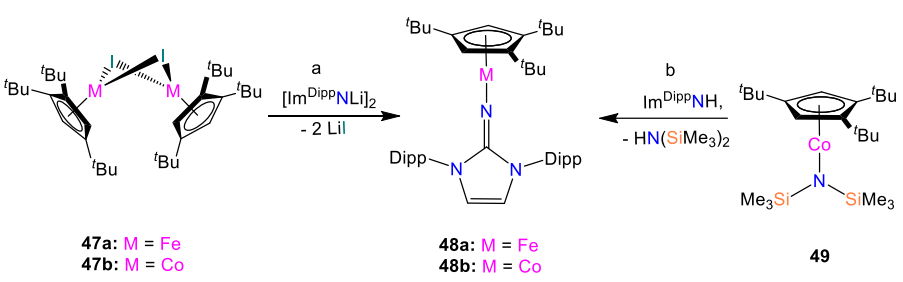

Scheme 29. Synthesis of 48 .

\subsection{Iron and cobalt complexes}

In 2019, Walter and co-workers reported the synthesis and magnetic properties of monomeric half-sandwich imidazolin2-iminato supported iron and cobalt complexes $\mathbf{4 8 a}$ and $\mathbf{4 8 b}$, respectively. ${ }^{[130]}$ The salt metathesis reaction between $\left[\mathrm{Cp}^{\prime} \mathrm{M}(\mu-\mathrm{I})\right]_{2} \quad\left(\mathrm{M}=\mathrm{Fe}, \mathrm{Co} ; \mathrm{Cp}^{\prime}=\eta^{5}\right.$-1,2,4-tri-tertbutylcyclopentadienyl) (47) and $\left[\mathrm{Im}^{\text {Dipp }} \mathrm{NLi}\right]_{2}$ afforded the iron (48a) and cobalt (48b) complexes in moderate yields (Scheme 29a). The alternate synthetic method of compound

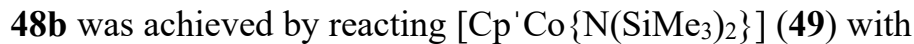
$\mathrm{Im}^{\text {Dipp }} \mathrm{NH}$ (Scheme 29b), which require high temperature compared to the previous process. The ${ }^{57} \mathrm{Fe}$ Mossbauer spectroscopy and solid-state magnetic susceptibility data 
confirmed that the central metal Fe(II) in 48a adopted a highspin $(S=2)$ state. Whereas the cobalt complex $48 b$, which is a rare example of a $\mathrm{Co}$ (II) system of not being a six coordinated species, displays a low-spin to high-spin spincrossover (SCO) behavior. The complex 48a exhibited pogostick geometry with the $\mathrm{Fe}-\mathrm{N}_{\text {imine }}$ bond length of $1.7885(13)$ $\AA$ and $\mathrm{Fe}-\mathrm{N}-\mathrm{C}$ bond angle of $171.45(8)^{\circ}$. The $\mathrm{Co}-\mathrm{N}$ bond length and $\mathrm{Co}-\mathrm{N}-\mathrm{C}$ bond angle of complex $\mathbf{4 8 b}$ are $1.721(4)$ $\AA$ and 173.1(3) ̊ respectively.

\section{Conclusions and Outlook}

In summary, we have covered recent trends in imidazolin-2iminato supported transition metal complexes and their applications in metathesis, polymerization of ethylene/ norbornene, RCAM, ROMP, etc. The catalytic activities of the compounds were shown to be tuned by wingtip alteration on $\mathrm{N}$ atom of imidazolin-2-iminato moieties. The titanium complexes $\mathbf{4}$ and $\mathbf{5}$ proved to be the highly active catalysts for the polymerization of propylene in the presence of MAO. Similarly, the titanium complexes $\mathbf{6}$ displayed an efficient activity in polymerization and co-polymerization of ethylene and ethylene/norbornene, respectively. The titanium complex $\mathrm{Im}^{\text {Dipp }} \mathrm{NTiClMe}_{2}$ exhibited a unique reactivity in ethylene polymerization reaction featuring an extremely low Al:Ti ratio of 20. Interestingly, the $\mathrm{Im}^{\mathrm{Mes}} \mathrm{NTiCl}_{3}$ (9) complex displayed the best catalytic activity so far reported for ethylene polymerization with MAO at a very low $\mathrm{Al}$ :Ti ratio of 8 . So overall, the imidazolin-2-iminato supported titanium complexes showed efficient catalytic activity and selectivity compared to other transition metal complexes. The zirconium complex 32 served as an efficient catalyst in ROP reactions. The hafnium complexes $\mathbf{3 3}$ and $\mathbf{3 4}$ exhibited excellent chemoselective reactivity in the hydroboration reaction. Similarly, the tungsten complex 39 also displayed enormous activities in RCAM and ACM reactions. The zinc complex $\mathbf{4 3}$ displayed efficient catalytic activity in the hydroboration of numerous aromatic and aliphatic nitriles. The (imido)vanadium(V) alkylidene complexes containing the imidazolidin-2-iminato ligand $\mathrm{V}\left(\mathrm{CHSiMe}_{3}\right)-(\mathrm{NR})(\mathrm{X})\left(\mathrm{PMe}_{3}\right)$ (where $\left.\mathrm{R}=\mathrm{Ph}, \mathrm{X}=1,3-\left(2,6-{ }^{i} \mathrm{Pr}_{2} \mathrm{C}_{6} \mathrm{H}_{3}\right)_{2}\left(\mathrm{CH}_{2} \mathrm{~N}\right)_{2} \mathrm{C}=\mathrm{N}\right)$ ) exhibited very high catalytic activities of ring-opening metathesis polymerization (ROMP) of norbornene (NBE) and achieved 7070 turnovers within 5 minutes at $80^{\circ} \mathrm{C}$. Thus, this compound could be utilized as a promising thermally robust olefin metathesis catalyst. Similarly, 37 proven to be an effective complex to activate $\mathrm{C}_{6} \mathrm{H}_{6}$ or $\mathrm{C}_{6} \mathrm{D}_{6}$ via $1,2-\mathrm{C}-\mathrm{H} / 1,2-$ $\mathrm{C}-\mathrm{D}$ activation. Thus this complex could be utilized further to activate polynuclear hydrocarbon or aromatic heterocyclic compounds. In the future, imidazolin-2-iminato ligands will continue their way to produce compounds that are green and sustainable. Despite the recent advancement of imidazolin-2iminato ligands in transition metals chemistry, documented in the current review, however, the effects of the ring expansion of N-heterocycle from 5 to $6 / 7$ in the catalytic performance of the resulted complexes need to be explored. The Nheterocyclic carbene (NHC) has already been a recognized candidate as a metal-free catalyst system. ${ }^{[131]}$ Nevertheless, the proficiency of more nucleophilic imidazolin-2-iminato is yet to investigate for this application. We also believe that the transition metal catalysts bearing N-heterocyclic iminato ligand can be used to perform a few important transformations of recent demand. For instance, the catalytic aptitude of these complexes and newly synthesized complexes might be explored for the generation of $\mathrm{H}_{2}$ and $\mathrm{O}_{2}$ via water splitting reactions and for efficient $\mathrm{C}$-capture processes.

\section{Acknowledgment}

We thank the anonymous reviewers for useful comments. Preethi Raja and Shanmugam Revathi acknowledge VIT University for providing fellowship. T.G. thanks VIT University for providing the "VIT SEED GRANT" and Science and Engineering Research Board (SERB), India for providing Start-up Research Grant (SRG/2020/000760).

\section{Support information}

Not applicable

\section{Conflict of Interest}

There are no conflicts to declare.

\section{References:}

[1] K. Öfele, J. Organomet. Chem., 1968, 12, 42-43, doi: 10.1016/S0022-328X(00)88691-X.

[2] H. W. Wanzlick, H. J. Schönherr, Angew. Chem. Int. Ed., 1968, 7, 141-142, doi: 10.1002/anie.196801412.

[3] D. J. Cardin, B. Cetinkaya, M. F. Lappert, L. J. ManojlovicMuir, K. W. Muir, J. Chem. Soc. D, 1971, 400-401, doi: 10.1039/C29710000400.

[4] W. A. Herrmann, C. Köcher, Angew. Chem. Int. Ed., 1997, 36, 2162-2187, doi: 10.1002/anie.199721621.

[5] W. A. Herrmann, Angew. Chem. Int. Ed., 2002, 41, 12901309, doi: 10.1002/1521-3773(20020415)41:8<1290:AIDANIE1290>3.0.CO;2-Y.

[6] D. Enders, T. Balensiefer, Acc. Chem. Res., 2004, 37, 534, doi: 10.1021/ar030050j.

[7] E. Peris, R. H. Crabtree, Coord. Chem. Rev., 2004, 248 2239, doi: 10.1016/j.ccr.2004.04.014.

[8] V. César, S. Bellemin-Laponnaz, L. H. Gade, Chem. Soc. Rev., 2004, 33, 619-636, doi: 10.1039/B406802P.

[9] H. Clavier, S. P. Nolan, Chem. Commun., 2010, 46, 841861,doi: 10.1039/B922984A.

[10] T. K. Sen, S. C. Sau, A. Mukherjee, P. K. Hota, S. K. Mandal, B. Maity, D. Koley, Dalton Trans., 2013, 42, 1425314260, doi:10.1039/C3DT51802G.

[11] S. Kaufhold, L. Petermann, R. Staehle, S. Rau, Coord. Chem. Rev., 2015, 304-305, 73-87, doi: 10.1016/j.ccr.2014.12.004.

[12] C. Romain, S. Bellemin-Laponnaz, S. Dagorne, Coord. Chem. Rev., 2020, 422, 213411, doi: 10.1016/j.ccr.2020.213411. 
[13] S. Shi, S. P. Nolan, M. Szostak, Acc. Chem. Res., 2018, 51, 2589-2599, doi: 10.1021/acs.accounts.8b00410.

[14] G. Prabusankar, A. Sathyanarayana, P. Suresh, C. N. Babu, K. Srinivas, B. P. R. Metla, Coord. Chem. Rev., 2014, 269, 96233, doi: 10.1016/j.ccr.2014.01.036.

[15] J. Liu, X.-N. Xing, J. -H. Huang, L.-Q. Lu, W. -J. Xiao, Chem. Sci., 2020, 11, 10605-10613, doi: 10.1039/D0SC03595E. [16] S. Ibanez, M. Poyatos, E. Peris, Acc. Chem. Res., 2020, 53, 1401-1413, doi: 10.1021/acs.accounts.0c00312.

[17] R. Durmaz, H. Küçükbay, E. Çetinkaya, B. Çetinkaya, Turk. J. Med. Sci., 1997, 27, 59-61, doi: 10.1107/S1600536804018835. [18] J. C. Garrison, W. J. Youngs, Chem. Rev., 2005, 105, 39784008, doi: 10.1021/cr050004s.

[19] L. Oehninger, H. Alborzinia, S. Ludewig, K. Baumann, S. Wölfl, I. Ott, Chem. Med. Chem., 2011, 6, 2142-2145, doi: 10.1002/cmdc.201100308.

[20] L. Oehninger, R. Rubbiani, I. Ott, Dalton Trans., 2013, 42, 3269-3284, doi: 10.1039/C2DT32617E.

[21] W. Zhao, V. Ferro, M. V. Baker, Coord. Chem. Rev., 2017, 339, 1-16, doi: 10.1016/j.ccr.2017.03.005.

[22] K. H. Park, I. Ku, H. J. Kim, S. U. Son, Chem. Mater., 2008, 20, 1673-1675, doi: 10.1021/cm702776r.

[23] L. Mercs, M. Albrecht, Chem. Soc. Rev., 2010, 39, $1903-$ 1912,doi: 10.1039/B902238B.

[24] A. Monge-Marcet, R. Pleixats, X. Cattoën, M. W. C. Man, Tetrahedron, 2013, 69, 341-348, doi: 10.1016/j.tet.2012.10.023.

[25] W. A. Herrmann, C.-P Reisinger, M. Spiegler, J. Organomet. Chem., 1998, 557, 93-96, doi: 10.1016/S0022-328X(97)00736-5.

[26] H. M. Lee, C. -C. Lee, P.-Y. Cheng, Curr. Org. Chem., 2007, 11, 1491-1524, doi: 10.2174/138527207782418681.

[27] E. M. Phillips, A. Chan, K. A. Scheidt, Aldrichimica Acta, 2009, 42, 55-66.

[28] D. Enders, O. Niemeier, A. Henseler, Chem. Rev., 2007, 107, 5606-5655, doi: 10.1021/cr068372z.

[29] N. Marion, S. Díez-González, S. P. Nolan, Angew. Chem., Int. Ed.,2007, 46, 2988-3000, doi: 10.1002/anie.200603380.

[30] M. N. Hopkinson, C. Richter, M. Schedler, F. Glorius, Nature, 2014, 510, 485-496, doi: 10.1038/nature13384.

[31] M. Y. Leow, C. C. Ho, M. G. Gardiner, A. C. Bissember, Catalysts, 2018, 8, 620, doi: 10.3390/catal8120620.

[32] M. -L. Teyssot, A. -S. Jarrousse, A. Chevry, A. D. Haze, C. Beaudoin, M. Manin, S. P. Nolan, S. D, González, L. Morel, A. Gautier, Chem. Eur. J., 2009, 15, 314-318, doi: 10.1002/chem.200801992.

[33] T. Li, J. Zhang, C. Cui, Chem. Asian. J., 2017, 12, 1218 1223, doi: 10.1002/asia.201700050.

[34] Y. Wang, T. Szilvasi, S. Yao, M. Driess, Nat. Chem., 2020. 12, 801-807, doi: 10.1038/s41557-020-0518-0.

[35] C. Shan, S. Yao, M. Driess, Chem. Soc. Rev., 2020, 49, 6733-6754, doi: 10.1039/D0CS00815J.
[36] Y. -P. Zhou, M. Driess, Angew. Chem. Int. Ed., 2019, 58, 3715-3728, doi: 10.1002/anie.201811088.

[37] H. Cui, Y. Shao, X. Li, L. Kong, C. Cui, Organometallics, 2009, 28, 5191-5195, doi: 10.1021/om900444z.

[38] J. Li, B. Ma, C. Cui, Organometallics, 2016, 35, 1358-1360, doi: 10.1021/acs.organomet.6b00152.

[39] M. Majumdar, V. Huch, I. Bejan, A. Meltzer, D. Scheschkewitz, Angew. Chem. Int. Ed., 2013, 52, 3516-3520, doi: 10.1002/anie.201209281.

[40] N. Kuhn, M. Gohner, G. Frenking, Y. Chen, Unusual Structures and Physical Properties in Organometallic Chemistry, wiley publication, 2003, 337.

[41] D. Petrovic, M. Tamm, E. Herdtweck, Acta Crystallogr. C., 2006, C62, 217-219, doi: 10.1107/S0108270106008778.

[42] A. G. Trambitas, J. Yang, D. Melcher, C. G. Daniliuc, P. G. Jones, Z. Xie, M. Tamm, Organometallics, 2011, 30, 1122-1129, doi: 10.1021/om1011243.

[43] I. S. Karmel, M. Botoshansky, M. Tamm, M. S. Eisen, Inorg. Chem., 2014, 53, 694-696, doi: 10.1021/ic402806x.

[44] A. Levens, F. An, M. Breugst, H. Mayr, D. W. Lupton, Org. Lett., 2016, 18, 3566-3569, doi: 10.1021/acs.orglett.6b01525.

[45] T. Ochiai, D. Franz, S. Inoue, Chem. Soc. Rev., 2016, 45, 6327-6344, doi: 10.1039/C6CS00163G.

[46] M. Castillo, O. Barreda, A. K. Maity, B. Barraza, J. Lu, A. J. Metta-Magaña, S. Fortier, J. Coord. Chem., 2016, 69, 20032014, doi: 10.1080/00958972.2016.1167198.

[47] A. Doddi, M. Peters, M. Tamm, Chem. Rev., 2019, 119, 6994-7112, doi: 10.1021/acs.chemrev.8b00791.

[48] M. Peters, D. Baabe, M. Maekawa, D. Bockfeld, M.-K. Zaretzke, M. Tamm, M. D. Walter, Inorg. Chem., 2019, 58, 16475-16486, doi: 10.1021/acs.inorgchem.9b02411.

[49] T. Ghatak, N. Fridman, M. S. Eisen, Organometallics, 2017, 36, 1296-1302, doi: 10.1021/acs.organomet.7b00037.

[50] S. Drucker, N. Fridman, M. S. Eisen, Dalton Trans., 2017, 47, 12005-12009, doi: 10.1039/C7DT02126G.

[51] H. Liu, N. Fridman, M. Tamm, M. S. Eisen, Organometallics, 2017, 36, 3896-3903, doi: 10.1021/acs.organomet.7b00502.

[52] X. Wu, M. Tamm, Coord. Chem. Rev., 2014, 260, 116-138, doi: 10.1016/j.ccr.2013.10.007.

[53] M. Tamm, D. Petrovic, S. Randoll, S. Beer, T. Bannenberg, P. G. Jones, J. Grunenberg, Org. Biomol. Chem., 2007, 5, 523530, doi: 10.1039/B615418B.

[54] M. Tamm, S. Randoll, E. Herdtweck, N. Kleigrewe, G. Kehr, G. Erker, B. Rieger, Dalton Trans., 2006, 459-467, doi: 10.1039/B511752F.

[55] N. Kuhn, R. Fawzi, M. Steimann, J. Wiethoff, D. Bläser, R. Boese, Z. Naturforsch. B., 1995, 50, 1779-1784, doi: 10.1515/znb-1995-1202. 
[56] N. Kuhn, R. Fawzi, M. Steimann, J. Wiethoff, D. Bl“aser and R. Boese, Z. Naturforsch., B: Chem. Sci., 1995, 50,17791784 and refs cited therein. doi: 10.1515/znb-1995-1202.

[57] M. Tamm, S. Randoll, T. Bannenberg, E. Herdtweck, Chem. Comm., 2004, 876-877, doi: 10.1039/B615418B.

[58] K. Dehnicke, A. Greiner, Angew. Chem. Int. Ed., 2003, 42 1340-1354, doi: 10.1002/anie.200390346.

[59] W. P. Kretschmer, C. Dijkhuis, A. Meetsma, B. Hessen, J. H. Teuben, Chem. Comm., 2002, 608-609, doi: 10.1039/B111343G.

[60] D. Shoken, M. Sharma, M. Botoshansky, M. Tamm, M. S. Eisen, J. Am. Chem. Soc.,2013, 135, 12592-12595, doi: $10.1021 / \mathrm{ja} 406925 \mathrm{z}$.

[61] K. Nomura, H. Fukuda, W. Apisuk, A. G. Trambitas, B. Kitiyanan, M. Tamm, J. Mol. Catal. A Chem., 2012, 363, 501511, doi: 10.1016/j.molcata.2012.08.001.

[62] W. Apisuk, A. G. Trambitas, B. Kitiyanan, M. Tamm, K. Nomura, J. Polym. Sci., Part A: Polym. Chem., 2013, 51, 25752580, doi: 10.1002/pola.26638.

[63] M. Sharma, H. S. Yameen, B. Tumanskii, S.-A. Filimon, M. Tamm, M. S. Eisen, J. Am. Chem. Soc., 2012, 134, 17234-17244, doi: $10.1021 / \mathrm{ja} 3071545$.

[64] S. H. Stelzig, M. Tamm, R. M. Waymouth, J. Polym. Sci., Part A: Polym. Chem., 2008, 46, 6064-6070, doi: 10.1002/pola.22918.

[65] M. Tamm, A. Kunst, M. Stadler, E. Herdtweck, Organometallics, 2007, 26, 761-764, doi: 10.1021/om0609564.

[66] D. Shoken, L. J. Shimon, M. Tamm, M. S. Eisen, Organometallics, 2016, 35, 1125-1131, doi: 10.1021/acs.organomet.6b00117.

[67] K. Naktode, S. Das, J. Bhattacharjee, H. P. Nayek, T. K. Panda, Inorg. Chem., 2016, 55, 1142-1153, doi: 10.1021/acs.inorgchem.5b02302.

[68] K. Naktode, S. Das, H. P. Nayek, T. K. Panda, J. Coord. Chem., 2018, 71, 4148-4163, doi: 10.1080/00958972.2018.1544 705.

[69] R. Rajput, A. P. Mishra, Int. J. Pharm. Sci. Res., 2012, 4, 66-70.

[70] G. Sharma, A. R. Robert, Int. J. Adv. Pharm. Bio. Chem. 2012, 1, 337-341.

[71] I. Khan, A. Ibrar, N. Abbas, A. Saeed, Eur. J. Med. Chem., 2014, 76, 193-244, doi: 10.1016/j.ejmech.2014.02.005.

[72] M. Asif, Int. J. Adv. Res. Chem. Sci., 2014, 1, 22-28, doi: 10.1.1.675.7787\&rep=rep1\&type=pdf.

[73] L. He, H. Li, J. Chen, X.-F. Wu, RSC Adv., 2014, 4, 12065 12077, doi: 10.1039/C4RA00351A.

[74] R. Ranjith, Int. J. Chem. Pharm. Res., 2016, 8, 505-526.
[75] A. Hameed, M. Al-Rashida, M. Uroos, S. A. Ali, Arshia, M. Ishtiaq, K. M. Khan, Expert Opin. Ther. Pat., 2018, 28, 281-297, doi: 10.1080/13543776.2018.1432596.

[76] K. C Majumdar, P. Debnath, N. De, B. Roy, Curr. Org. Chem., 2011, 15, 1760-1801, doi: 10.2174/13852721179565663 3.

[77] A. V. Gulevich, A. S. Dudnik, N. Chernyak, V. Gevorgyan, Chem. Rev., 2013, 113, 3084-3213, doi: 10.1021/cr300333u.

[78] P. W. Davies, M. Garzón, Asian J. Org. Chem., 2015, 4, 694-708, doi: 10.1002/ajoc.201500170.

[79] X. Huang, H. Yang, H. Fu, R. Qiao, Y. Zhao, Synthesis, 2009, 16, 2679-2688, doi: 10.1055/s-0029-1216871.

[80] S. Das, J. Bhattacharjee, T. K. Panda, Dalton Trans., 2019, 48, 7227-7235, doi: 10.1039/C8DT04630A.

[81] K. Naktode, S. Das, J. Bhattacharjee, H. P. Nayek, T. K. Panda, Inorg. Chem., 2016, 55, 1142-1153, doi: 10.1021/acs.inorgchem.5b02302.

[82] A. Glöckner, T. Bannenberg, C. G. Daniliuc, P. G. Jones, M. Tamm, Inorg. Chem., 2012, 51, 4368-4378, doi: 10.1021/ic300129z.

[83] A. Glöckner, T. Bannenberg, M. Tamm, A. M. Arif, R. D. Ernst, Organometallics, 2009, 28, 5866-5876, doi: 10.1021/om900456s.

[84] A. Glöckner, A. M. Arif, R. D. Ernst, T. Bannenberg, C. G. Daniliuc, P. G. Jones, M. Tamm, Inorganica Chim. Acta., 2010, 364, 23-29, doi: 10.1016/j.ica.2010.06.049.

[85] A. Glöckner, M. Tamm, Chem. Soc. Rev., 2013, 42, 128-142, doi: 10.1039/C2CS35321K.

[86] A. Glöckner, M. Tamm, A. M. Arif, R. D. Ernst, Organometallics, 2009, 28, 7041-7046, doi: 10.1021/om900847y [87] A. Glöckner, T. Bannenberg, S. Büschel, C. G. Daniliuc, P. G. Jones, M. Tamm, Chem. Eur. J., 2011, 17, 6118-6128, doi: 10.1002/chem.201100104.

[88] A. Glöckner, C. G. Daniliuc, M. Freytag, P. G. Jones, M. Tamm, Chem. Comm., 2012, 48, 6598-6600, doi: 10.1039/C2CC32961A.

[89] A. Glöckner, H. Bauer, M. Maekawa, T. Bannenberg, C. G. Daniliuc, P. G. Jones, Y. Sun, H. Sitzmann, M. Tamm, M. D. Walter, Dalton Trans., 2012, 4, 6614-6624, doi: 10.1039/C2DT12132H.

[90] S. C. Dunn, N. Hazari, A. R. Cowley, J. C. Green, P. Mountford, Organometallics, 2006, 25, 1755-1770, doi: 10.1021/om0510526.

[91] M. L. H. Green, D. K. P. Ng, Chem. Rev., 1995, 95, 439473, doi: 10.1021/cr00034a006.

[92] M. Khononov, N. Fridman, M. Tamm, M. S. Eisen, Eur. J. Org. Chem., 2020, 2020, 3153-3160, doi: 10.1002/ejoc. 201901750 
[93] E. W. M. Haynes, CRC Handbook of Chemistry and Physics, CRC Press/Taylor and Francis, Boca Raton, FL, 2016.

[94] K. Nomura, W. Zhang, Chem. Sci., 2010, 1, 161-173, doi: 10.1039/C0SC00163E.

[95] K. Nomura, B. K. Bahuleyan, K. Tsutsumi, A. Igarashi, Organometallics, 2014, 33, 6682-6691, doi: /10.1021/om500986m. [96] J. Yi, W. Yang, W.-H. Sun, K. Nomura, M. Hada, J. Phys. Chem. A., 2017, 121, 9099-9105, doi: 10.1021/acs.jpca.7b08328. [97] S. Zhang, M. Tamm, K. Nomura. Organometallics, 2011, 30, 2712-2720, doi: 10.1021/om200086n

[98] S. Zhang, K. Nomura, J. Am. Chem. Soc., 2010, 132, 49604965, doi: 10.1021/ja100573d.

[99] K. Nomura, B. K. Bahuleyan, S. Zhang, P. M. Veeresha Sharma, S. Katao, A. Igarashi, A. Inagaki, M. Tamm, Inorg. Chem., 2014, 53, 607-623, doi: 10.1021/ic402747d.

[100] R. R. Schrock, Acc. Chem. Res., 1986, 19, 342-348, doi: 10.1021/ar00131a003.

[101] R. R. Schrock, A. H. Hoveyda, Angew. Chem. Int. Ed., 2003, 42, 4592-4633, doi: 10.1002/anie.200300576.

[102] R. R. Schrock, J. Mol. Catal. A Chem., 2004, 213, 21-30, doi: 10.1016/j.molcata.2003.10.060.

[103] R. R. Schrock, Chem. Comm., 2005, 22, 2773-2777, doi: 10.1039/B504541J.

[104] R. R. Schrock, C. Czekelius, Adv. Synth. Catal., 2007, 349, 55-77, doi: 10.1002/adsc.200600459.

[105] S. Beer, C. G. Hrib, P. G. Jones, K. Brandhorst, J. Grunenberg, M. Tamm, Angew. Chem., 2007, 119, 9047-9051, doi: 10.1002/ange.200703184.

[106] S. Beer, K. Brandhorst, C. G. Hrib, X. Wu, B. Haberlag, J. Grunenberg, P. G. Jones, M. Tamm, Organometallics, 2009, 28, 1534-1545, doi: 10.1021/om801119t.

[107] Z. S. Qureshi, A. Hamieh, S. Barman, N. Maity, M. K. Samantaray, S. Ould-Chikh, E. Abou-Hamad, L. Falivene, V. D'elia, A. Rothenberger, Inorg. Chem., 2017, 56, 861-871, doi: 10.1021/acs.inorgchem.6b02424.

[108] R. R. Schrock, R. T. DePue, J. Feldman, K. B. Yap, D.C. Yang, W. M. Davis, L. Park, M. DiMare, M. Schofield, J. Anhaus, E. Walborsky, E. Evitt, C. Kruger, P. Betz, Organometallics, 1990, 9, 2262-2275, doi: 10.1021/om00158a025.

[109] R. R. Schrock, R. T. DePue, J. Feldman, C. J. Schaverien, J. C. Dewan, A. H. Liu, J. Am.Chem. Soc., 1988, 110, 1423-1435, doi: $10.1021 / \mathrm{ja} 00213 \mathrm{a} 014$.

[110] F. J. Gomez, M. S. Manak, K. A. Abboud, K. B. Wagener, J. Mol. Catal. A: Chem., 2000, 160, 145-156, doi: 10.1016/S1381-1169(00)00241-7.

[111] D. V. Peryshkov, R. R. Schrock, Organometallics, 2012, 31, 7278-7286, doi: 10.1021/om3008579.

[112] A. Fürstner, Synthesis, 1989, 1989, 571-590, doi: 10.1055/s-1989-27326.
[113] P. Knochel, P. Jones, Oxford University Press, 1999.

[114] W. A. Herrmann. SYNTHESIS-STUTTGART, 1999,1, 834-834.

[115] R. L. Shriner, Org. React., 2004, 1, 1-37, doi: .1002/0471264180.or001.01.

[116] A. O. King, N. Okukado, E.-i. Negishi, J. Chem. Soc., Chem. Commun., 1977, 19, 683-684, doi: 10.1039/C39770000683.

[117] E. Negishi, A. O. King, N. Okukado, J. Org. Chem., 1977, 42, 1821-1823, doi: 10.1021/jo00430a041.

[118] P. Walla, C. O. Kappe, Chem. Comm., 2004, 564-565, doi: 10.1039/B313887A.

[119] M. R. Luzung, J. S. Patel, J. Yin, J. Org. Chem., 2010, 75, 8330-8332, doi: 10.1021/jo1018798.

[120] W. Kläui, U. Schilde, M. Schmidt, Inorg. Chem., 1997, 36, 1598-1601, doi: 10.1021/ic961249d.

[121] X. F. Wu, Chem. Asian. J., 2012, 7, 2502-2509, doi: 10.1002/asia.201200596.

[122] A. H. Cherney, S. E. Reisman, Tetrahedron, 2014, 70, 3259-3265, doi: 10.1016/j.tet.2013.11.104.

[123] R. Oost, A. Misale, N. Maulide, Angew. Chem., 2016, 128, 4663-4666, doi: 10.1002/ange.201600597.

[124] S. Dagorne, Synthesis, 2018, 50, 3662-3670, doi: 10.1055/s-0037-1610088.

[125] S. Das, J. Bhattacharjee, T. K. Panda, New J. Chem., 2019, 43, 16812-16818, doi: 10.1039/C9NJ04076E.

[126] H. Liu, M. Khononov, N. Fridman, M. Tamm, M. S. Eisen, Inorg. Chem., 2019, 58, 13426-13439, doi: 10.1021/acs.inorgchem.9b02324

[127] M. Krieger, R. O. Gould, B. Neumuller, K. Harms, K. Dehnicke, Z. Anorg. Allg. Chem., 1998, 624, 1434-1442, doi: 10.1002/(SICI)1521-3749(199809)624:9<1434::AID-

ZAAC1434>3.0.CO;2-7

[128] T. L. Cleland, S. D. Bunge, Polyhedron, 2007, 26, 55065512, doi: 10.1016/j.poly.2007.08.013

[129] S. D. Bunge, J. A. Bertke, T. L. Cleland, Inorg. Chem., 2009, 48, 8037-8043, doi: 10.1021/ic9007153

[130] M. Peters, D. Baabe, M. Maekawa, D. Bockfeld, M. -K. Zaretzke, M. Tamm, M. D. Walter, Inorg. Chem., 2019, 58, 16475-16486, doi: 10.1021/acs.inorgchem.9b02411

[131] E. Blondiaux, J. Pouessel, T. Cantat, Angew. Chem. Int. Ed., 2014, 53, 12186-12190, doi: 10.1002/anie.201407357 


\section{Author information}

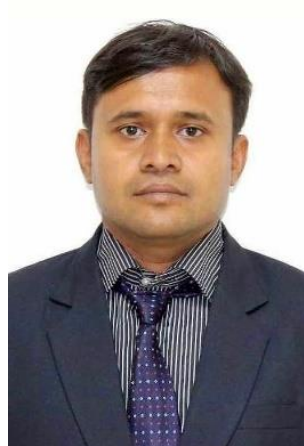

Tapas Ghatak received his MSc degree from the University of Kalyani in 2006 and completed his Ph.D. under the supervision of Prof. Jitendra K. Bera in 2014 from the Indian Institute of Technology Kanpur. He continued post-doctoral studies at Israel Institute of Technology, Technion under the guidance of Prof. Moris S. Eisen from November 2014 till December 2017. In 2018, he joined as an assistant professor at the department ofapplied chemistry in Govt. engineering college, Jabalpur. Currently, he is an assistant professor at the Vellore Institute of Technology(VIT), Vellore. His current research interests are centered on the synthesis and reactivity investigation of early transition metal complexes to find novel applications in widely applicable organic transformations and small molecule $\left(\mathrm{CO}_{2}, \mathrm{H}_{2} \mathrm{O}\right.$, etc.) activations.

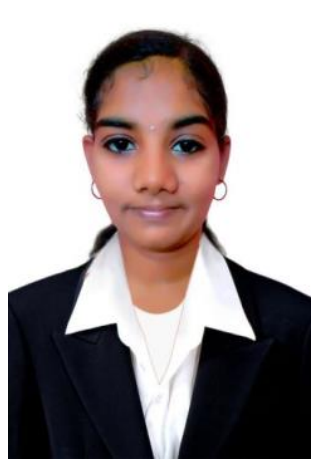

Preethi Raja was born in Chennai, Tamilnadu, India in 1997, and obtained her BSc from the Bharathi Women's College, Chennai in 2017. She received her MSc from Queen Mary's College, Chennai in 2019. Now, she is doing Ph.D. at Vellore Institute of Technology, Vellore, under the guidance of Dr. Tapas Ghatak in the field of organometallic chemistry and catalysis mediated by early transition

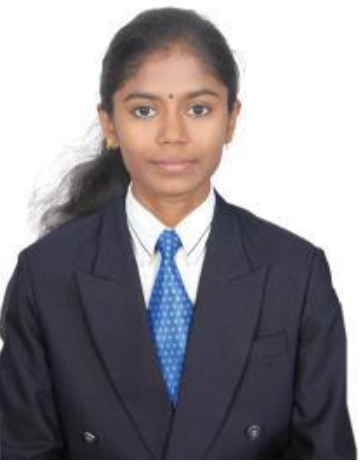

Shanmugam Revathi was born in Erode, Tamilnadu, India in 1997, and studied BSc Chemistry at Sri Vasavi College, Erode in 20142017. She received her MSc from Bharathiar University, Coimbatore in 2019. Now, she is pursuing a Ph.D. at Vellore Institute of Technology, Vellore, under the guidance of Dr. Tapas Ghatak in the field of organometallic andcatalysis mediated by early transition metal complexes.

Publisher's Note: Engineered Science Publisher remains neutral with regard to jurisdictional claims in published maps and institutional affiliations.

metal complexes. 